\title{
BADANIA NAD POCZĄTKAMI SZKLARSTWA I WYROBAMI SZKLANYMI NA ZIEMIACH POLSKICH: PROBLEMY I METODY BADAŃ. ZARYS
}

\author{
STUDIES ON THE ORIGINS OF GLASSMAKING AND GLASSWARE IN POLAND: \\ AN OUTLINE OF PROBLEMS AND RESEARCH METHODS
}

\begin{abstract}
The discovery of relics initially interpreted as a glasswork from the $11^{\text {th }}$ century that occurred in Kruszwica in 1953 was followed by increased interest in glassware found at excavations in Poland. Even though the later laboratory analyses from 1964 revealed that the discovered furnace was not directly connected with glassmaking, studies on production of glass became more frequent. They were conducted on two levels: 1 . by institutions related to glass industry, 2 . by archaeologists and historians in cooperation with chemists, physicians and technologists. The large amount of source material that consisted of glass-related finds obtained during the millennial excavations as well as establishing a research team comprised of representatives of different disciplines allowed for interdisciplinary studies on glassware and relics of glassmaking. They led to addressing theoretical foundations and methods of research on this category of finds. Numerous studies, including books and papers, were also published and a new scientific discipline, history of glass, was born in Poland.

KEY WORDS: Poland, Early Middle Ages, interdisciplinary studies on the finds connected with glassmaking, origins of glass-making
\end{abstract}

W historii badań nad wyrobami szklanymi znajdowanymi na terenie Polski można wyróżnić kilka okresów. Pierwszy z nich, kończący się mniej więcej w pierwszej połowie lat pięćdziesiątych XX w., charakteryzuje się marginesowym i przeważnie zawężonym do cech zewnętrznych opisywanych znalezisk traktowaniem wyrobów szklanych oraz na ogół pomijaniem aspektów technologicznych. W niniejszych rozważaniach okres ten został pominięty (jego omówienie można znaleźć w literaturze przedmiotu, np. Olczak 1964, 309-317; Dekówna 2005b, 3-4).
Przedstawiono tu, zgodnie $\mathrm{z}$ tytułem konferencji, stan źródeł i badań w latach następnych, począwszy od pojawienia się pierwszych dowodów na istnienie wytwórczości szklarskiej na naszych ziemiach; były nimi odkrycia poczynione $\mathrm{w}$ wyniku badań archeologicznych głównych ośrodków wczesnopiastowskich, prowadzonych w ramach przygotowania obchodów tysiąclecia Państwa Polskiego. Tak więc głównym podmiotem zaprezentowanego w artykule przeglądu problemów i metod badawczych są przede wszystkim znaleziska wczesnośredniowiecz- 
ne; te datowane na inne okresy są tylko marginesowo uwzględnione. $\mathrm{Z}$ powodu limitowanej objętości pracy musiałam ograniczyć się do przedstawienia tu owej problematyki w formie bardzo skróconej, a w wykazie bibliografii zamieścić tylko pozycje podstawowe dla rozpatrywanych zagadnien.

\section{OD LAT PIECĆDZIESIACTYCH DO KOŃCA LAT SZEŚĆDZIESIACTYCH XX W. BADANIA MILLENIJNE. GROMADZENIE ŹRÓDEŁ. WYKSZTAŁCANIE SIĘ STRUKTUR ORGANIZACYJNYCH. PIERWSZE OPRACOWANIA}

Na wstępie posłużę się cytatem z jednej z prac Jerzego Olczaka. Otóż, w 1987 r. ówczesny doktor, Jerzy Olczak pisał: „...w dziejach badań nad historią polskiego przemysłu szklarskiego mamy datę [która] ... ma niezaprzeczalnie i dosłownie odkrywcze znaczenie dla historii tego przemysłu. Datą tą jest rok 1953, w którym na podgrodziu w Kruszwicy nad Gopłem archeolodzy odkryli pozostałości XI-wiecznej huty szkła”, i dalej: „Kruszwica stała się na długie lata swojego rodzaju symbolem polskiego szklarstwa" (Olczak 1987a, 13). Przypomnę, że odsłonięto tu piec kamienny i szereg otwartych palenisk glinianych oraz zmagazynowany surowiec $\mathrm{w}$ postaci skamieniałych, dość ciężkich bryłek (ryc. 1; Olczak 1987b, 28)1. Prowadząca wówczas badania wykopaliskowe na tym stanowisku Aleksandra Cofta-Broniewska uznała ów zespół za pozostałość pracowni szklarskiej, rekonstruując nawet technologię produkcji, która miała być w tym warsztacie stosowana (Cofta 1954, 224, 225; 1955 , 91-100). Jednak wykonane przez Michaiła A. Biezborodowa i Jerzego Olczaka analizy chemiczne i petrograficzne surowca oraz badania konstrukcji pieca i palenisk, których wyniki zostały opublikowane w 1964 r., wykazały, że budowa pieca i jego rozmiary wykluczają możliwość prowadzenia w nim wytopu szkła, a surowiec, który - jak wykazano - składał się tylko z piasku i wapnia, mógł być najwyżej częściowo przygotowanym zestawem (by otrzymać szkło, trzeba by było uzupełnić go jeszcze innymi składnikami szkłotwórczymi). Jak stwierdzili obaj badacze, piec mógł służyć tylko do suszenia piasku, który mógł być wykorzystywany do różnego rodzaju wytwórczości (Biezborodow, Olczak 1964; Olczak 1968, 81-115). W latach na-

1 Ryciny i tabela zamieszczone w niniejszym artykule zostały opracowane komputerowo przez dra Tomasza Purowskiego, któremu składam z tego tytułu podziękowania. Pani dr Jolancie Sadowskiej-Topór dziękuję za wykonanie niektórych prac technicznych związanych z przygotowaniem artykułu do druku. stępnych znajdowano jednak w Kruszwicy różne odpady produkcyjne, które świadczą o istnieniu tu jakiejś formy wytwórczości szklarskiej, ale wspomnianego zespołu nie można interpretować jako pozostałości huty szkła (Olczak 1968, 115-148; 1987b, 28-30; Dekówna 1992, 386-389, 400). Mimo to i mimo iż ślady produkcji szkła ujawniano, w wyniku prac wykopaliskowych, także w innych miejscach - w Wolinie, Opolu, Wrocławiu (Olczak 1959; 1968, 18-19, 148-181; Dekówna 1992, 384386, 389, 401-402), to właśnie odkrycie w Kruszwicy spowodowało wzrost zainteresowania możliwością istnienia rodzimej wytwórczości szklarskiej w Polsce. Zainteresowały się nimi przede wszystkim instytucje związane ze współczesnym przemysłem szklarskim.

I tak, w końcu lat pięćdziesiątych XX w. Sekcja Szkła Stowarzyszenia Inżynierów i Techników Przemysłu Chemicznego wystapiła $\mathrm{z}$ inicjatywą włączenia do badań millenijnych także badań nad początkami szklarstwa polskiego. Powołano zespół, którego przewodniczącym został ówczesny mgr inż. Włodzimierz Świetlik; opracował on program Obchodów 1000-lecia Polskiego Hutnictwa Szklarskiego, który został zaakceptowany w połowie 1959 r. przez Ministerstwo Budownictwa i Przemysłu Materiałów Budowlanych oraz dyrekcję Zjednoczenia Przemysłu Szklarskiego. W 1960 r. W. Świetlik przedstawił ten projekt prof. Stanisławowi Lorentzowi, dyrektorowi Naczelnej Dyrekcji Muzeów i Ochrony Zabytków przy Ministerstwie Kultury i Sztuki², będącemu również

2 W 1949 r. przy Naczelnej Dyrekcji Muzeów i Ochrony Zabytków powołano Kierownictwo Badań nad Początkami Państwa Polskiego (nazwa tej instytucji ulegała z biegiem czasu niewielkim zmianom, por. Labuda 1987, 9; Kiersnowski 2000, 62; Abramowicz 2005, 195; Dekówna 2008, 55-56 - tu podana też starsza literatura). Panią Profesor dr hab. Martę Młynarską-Kaletynową proszę o przyjęcie wyrazów wdzięczności za przekonsultowanie kwestii dotyczących powstania struktur organizacyjnych badań millenijnych. 

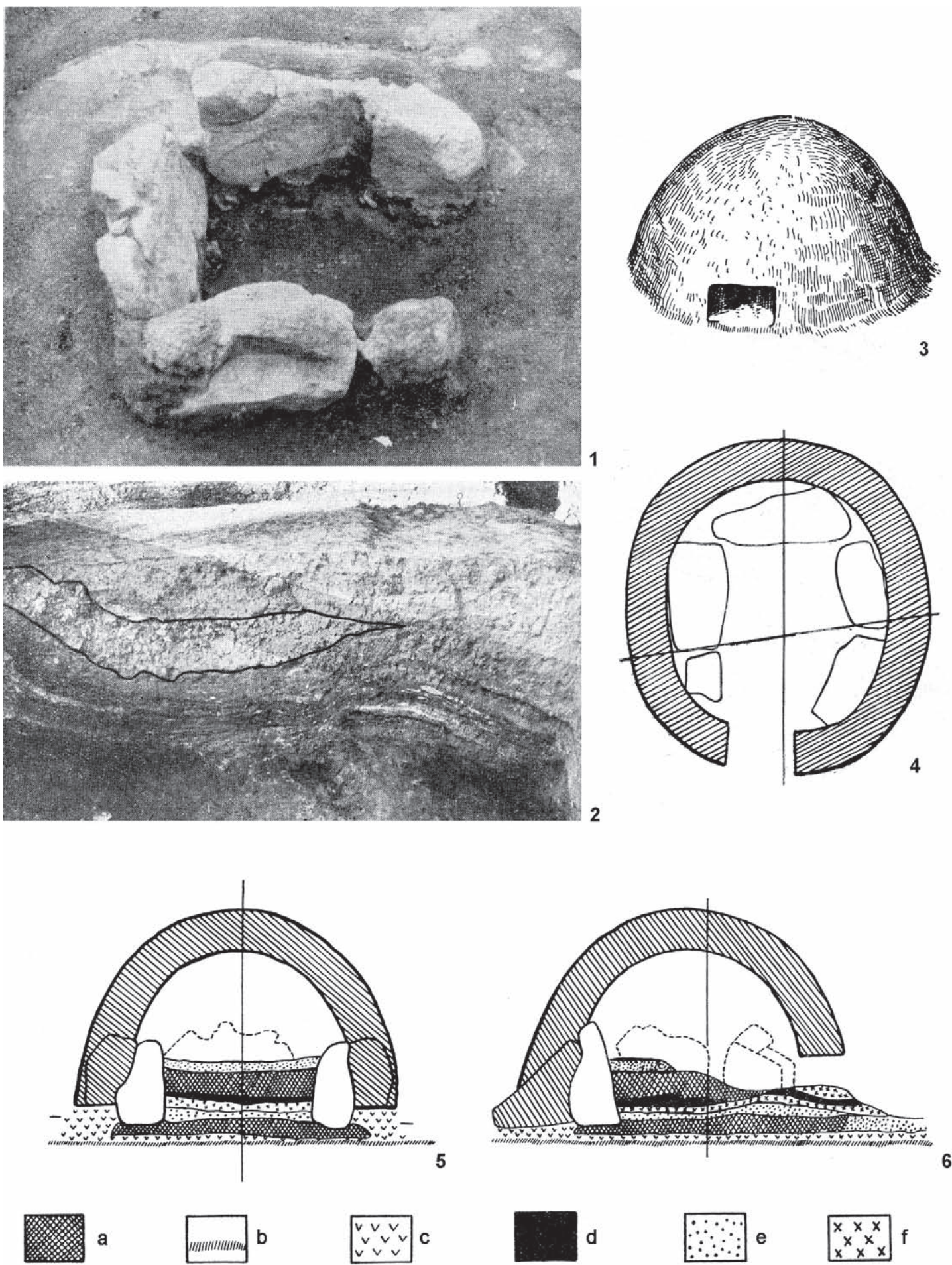

Ryc. 1. Kruszwica, pow. inowrocławski, stanowisko 4. Piec kamienny: 1 - konstrukcja pieca, widok z góry, od zachodu; 2 - przekrój „,magazynu” z domniemanym surowcem szklarskim; 3, 4 - rekonstrukcja pieca: widok z boku (3) i rzut poziomy (4); 5, 6 - rekonstrukcja pieca: przekroje ze zrekonstruowaną kopułą glinianą: a - domniemany surowiec szklarski; b - podłoga drewniana; c - warstwa kulturowa; d - spalenizna; e - glina; f - popiół. Bez skali. (Olczak 1968, ryc. 14 (1); Biezborodow, Olczak 1964, ryc. 5 (2); Cofta-Broniewska, cytuję za Olczakiem 1968, ryc. 15 (3, 4) i 16 (5, 6)

Fig. 1. Kruszwica, Inowrocław district, site 4 . The stone furnace: 1 - the construction of the furnace, the top view from the West; 2 - the section of a "storage" with supposed raw material; 3, 4-a reconstruction of the furnace: the side view (3) and the plan view (4); 5, 6- a reconstruction of the furnace: the section views with a reconstructed clay dome: $\mathrm{a}$ - possibly raw material; b - wooden floor; c - cultural layer; $\mathrm{d}$ - burnt material; e - clay; $\mathrm{f}$ - ash. No scale.

(Olczak 1968, Fig. 14 (1); Biezborodow, Olczak 1964, Fig. 5 (2); Cofta-Broniewska, from Olczak 1968, Fig. $15(3,4)$ and $16(5,6)$ 
przewodniczącym, powstałego w tym roku, Polskiego Komitetu Narodowego Międzynarodowego Stowarzyszenia do Badań Historii Szkła (Journées Internationales du Verre, a od 1967 r. Association Internationale pour l'Histoire du Verre). Włodzimierz Świetlik został wówczas mianowany jednym z wiceprzewodniczących Komitetu (Olczak 1960; Kamieńska 1966, 728; Dekówna 2005a, 223; 2016, 369). Mniej więcej od tego czasu badania nad początkami szklarstwa polskiego były prowadzone dwutorowo: 1. przez instytucje związane z przemysłem szklarskim, 2. przez archeologów i historyków skupionych w Polskim Komitecie Narodowym.

Jeśli chodzi o pierwszy nurt, to przedstawiciele przemysłu skoncentrowali się na przygotowaniu obchodów 1000-lecia szklarstwa polskiego. Między innymi podjęto decyzję o stworzeniu w Kruszwicy skansenu, w którym miała znaleźć się rekonstrukcja wczesnośredniowiecznej huty szkła. Opracowanie projektu zlecono Biuru Projektów Przemysłu Szklarskiego. Po ogłoszeniu wyników badań M.A. Biezborodowa i J. Olczaka zaniechano jego realizacji ${ }^{3}$. Wydano natomiast specjalny zeszyt czasopisma „Szkło i Ceramika” (ukazał się drukiem we wrześniu 1966 r.; ryc. 2: 1), w którym opublikowano artykuły poświęcone stanowi badań nad szkłem i szklarstwem w Polsce od pradziejów po XX wiek (966-1966. 1000 lat... 1966) oraz zorganizowano w Krośnie sesję naukową; wygłosili na niej referaty archeolodzy, historycy i technolodzy.

W Polskim Komitecie Narodowym organizację prac dotyczących badań nad początkami szklarstwa polskiego prof. S. Lorentz powierzył prof. dr Zofii Kamieńskiej, którą powołał na stanowisko wiceprzewodniczącej Komitetu. Zofia Kamieńska była wówczas kierownikiem Pracowni Historii Rzemiosł i Wytwórczości Przemysłowej w Zakładzie Historii Kultury Materialnej Średniowiecza i Czasów Nowożytnych Instytutu Historii Kultury Materialnej Polskiej Akademii Nauk (dalej: IHKM PAN). W 1962 r. przedstawiła ambitny plan przeprowadzenia badań nad mało znanymi wycinkami dziejów szkła w Polsce i następnie opracowania historii tej gałęzi wytwórczości na naszych ziemiach (Kamieńska 1966, 730; Olczak 1991, 9; Dekówna 1997, 280-282). Bardzo szybko przygotowała, wraz z mgr Haliną Chojnacką i doc. Stanisławem Gebethnerem z Muzeum Narodowego w Warsza-

3 Informacja uzyskana od mgra inż. Lutosława Lichoty, ówczesnego pracownika tego Biura. wie, tom obrazujący stan źródeł i opracowań dotyczących historii szkła w Polsce od wczesnego średniowiecza po XX wiek, zawierający m.in. prezentację zbiorów szkła w naszym kraju. Został on opublikowany w 1963 r. w Belgii, jako nr 2 serii Bulletin des] ournées I nternational es du Verre(ryc. 2: 2; Le verre... 1963, 13-94).

Pani Zofia Kamieńska już na początku lat sześćdziesiątych ubiegłego stulecia zgromadziła w Komitecie duży zespół badaczy składający się $\mathrm{z}$ archeologów, historyków, historyków sztuki, chemików i technologów oraz zainicjowała systematyczne studia nad dziejami szkła w Polsce (Olczak 1991, 9). Dzięki finansowemu wsparciu instytucji związanych z przemysłem szklarskim wykonano pierwsze analizy składu chemicznego szkła przedmiotów pochodzących $\mathrm{z}$ różnych okresów oraz przeprowadzono badania archiwalne. Powstałe na tej podstawie prace weszły w skład książki pt. Polskie szkło do połowy XIX wieku, której ukazały się dwa wydania (ryc. 2: 3; Polskie szkło... 1974; 1987). Było to pierwsze syntetyzujące ujęcie dziejów szkła w wymienionym okresie (w bardzo długim przedziale czasowym; Olczak 1991, 9).

Prowadzone na wielką skalę w ramach przygotowania obchodów tysiąclecia Państwa Polskiego prace wykopaliskowe na terenie głównych ośrodków wczesnopiastowskich dostarczyły wielu znalezisk wiążących się ze szklarstwem (gotowe wyroby, pozostałości produkcji). Zaczęto więc dostrzegać potrzebę opracowania metod badania tego rodzaju źródeł.

Z inicjatywy Pani Profesor pojawiły się pierwsze próby podejmowania takich tematów. Omawiano je m.in. na zorganizowanym przez Nia międzynarodowym spotkaniu dyskusyjnym, które odbyło się we wrześniu 1965 r. w Centralnym Laboratorium IHKM PAN w Warszawie, w którym wzięli udział polscy i zagraniczni badacze reprezentujący różne dyscypliny (ryc. 3). Współpraca z instytucjami związanymi z przemysłem szklarskim przyczyniła się, jak pisał Jerzy Olczak „,.. do przeniesienia na grunt metodyki archeologicznej (mam tu na myśli polską archeologię) niektórych metod i aparatury pojęciowej z nauk technicznych zajmujących się badaniem szkła współczesnego..." (Olczak 1987a, 14).

Dzięki Pani Profesor polskie środowisko naukowe zostało w latach sześćdziesiątych XX w. włączone w międzynarodowy nurt badań nad historią szkła. W 1966 r. przebywał w Polsce, na zapro- 

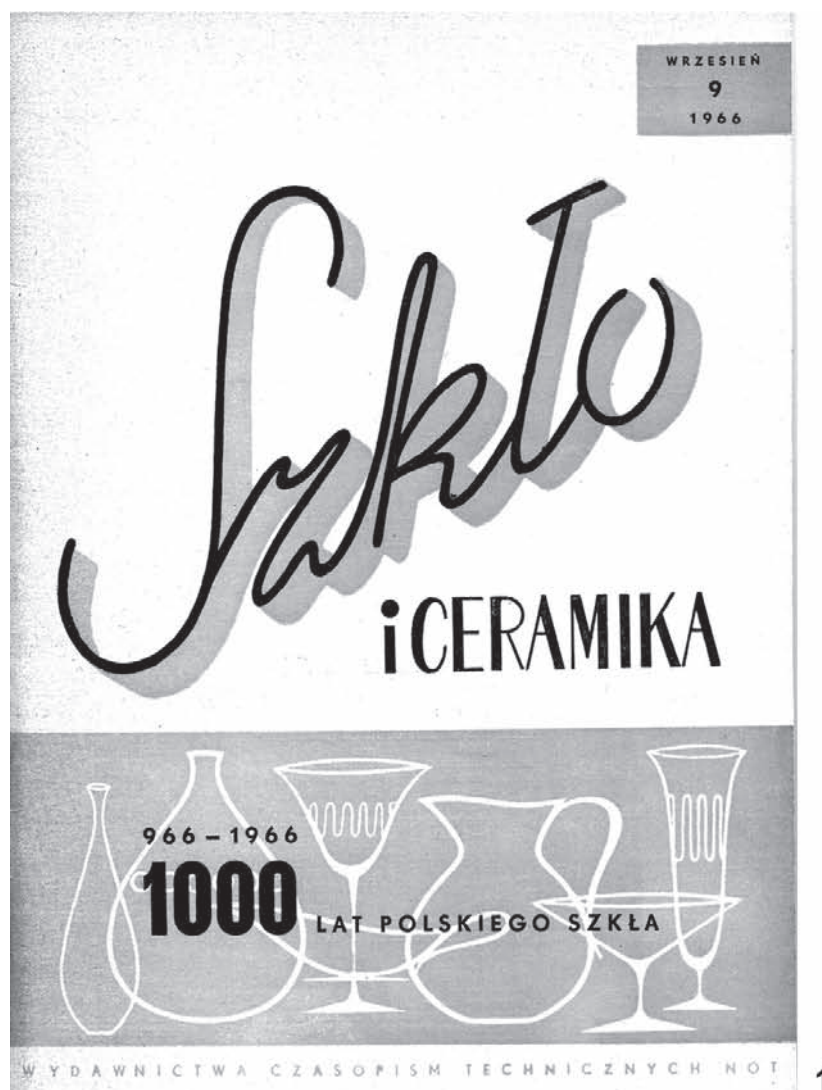

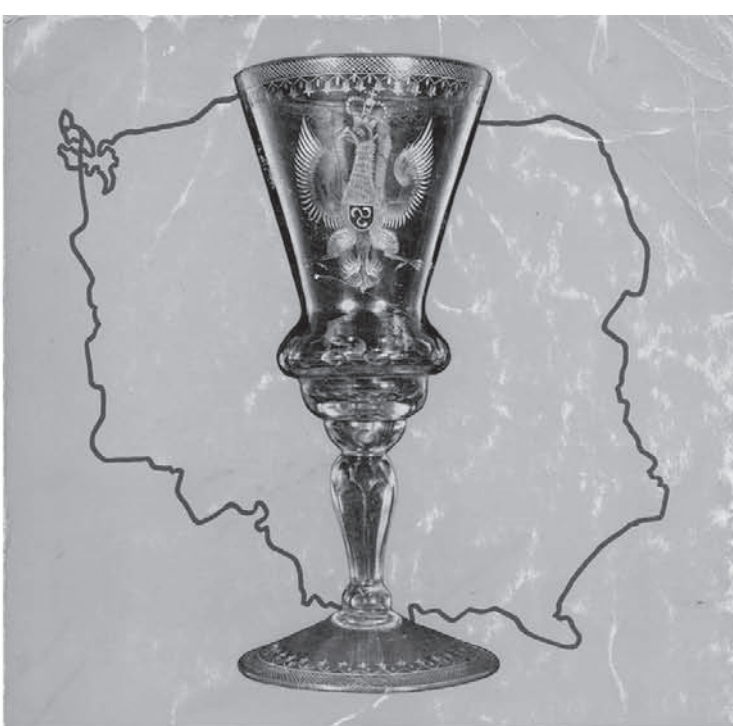

\section{BULLETIN DES}

JOURNÉES INTERNATIONALES

DU VERRE

$\mathbf{N}^{\circ} 2 \quad-\quad 1963$

EDITION DU SECRÉTARIAT GENEERAL PERMANENT A LIËGE

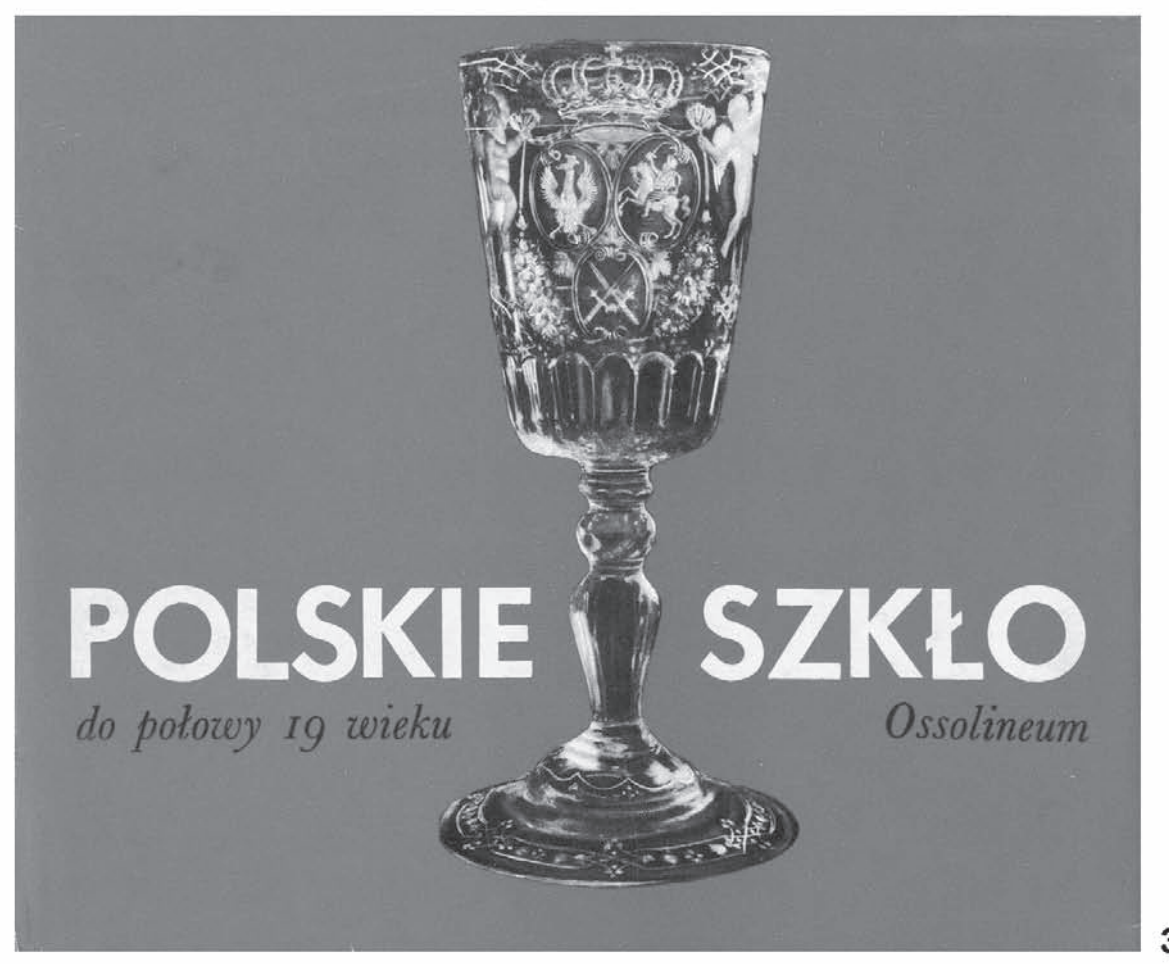

Ryc. 2. Pierwsze publikacje zawierające podsumowanie stanu badań nad dziejami szkła w Polsce: 1 - wydanie millenijne czasopisma Szkło i Ceramika 9, 1966; 2 - nr 2 serii Bulletin des J ournées Internationales du Verre 1963; 3 - pierwsze wydanie monografii Polskie szkło do połowy 19 wieku, Z. Kamieńska (red.), Wrocław-Warszawa-Kraków-Gdańsk 1974

Fig. 2. First publications summarizing the state of research on the history of glass in Poland: 1 - the millenial release of the journal Szkło i Ceramika (Glass and Pottery) 9, 1966; 2 - vol. 2 from the series Bulletin des J ournées I nternationales du Verre, 1963; 3 - the first edition of the monography Polskie szkło do połowy 19 wieku (Polish glass to the middle of the $19^{\text {th }}$ century), Z. Kamieńska (ed.), Wrocław-Warszawa-Kraków-Gdańsk 1974 

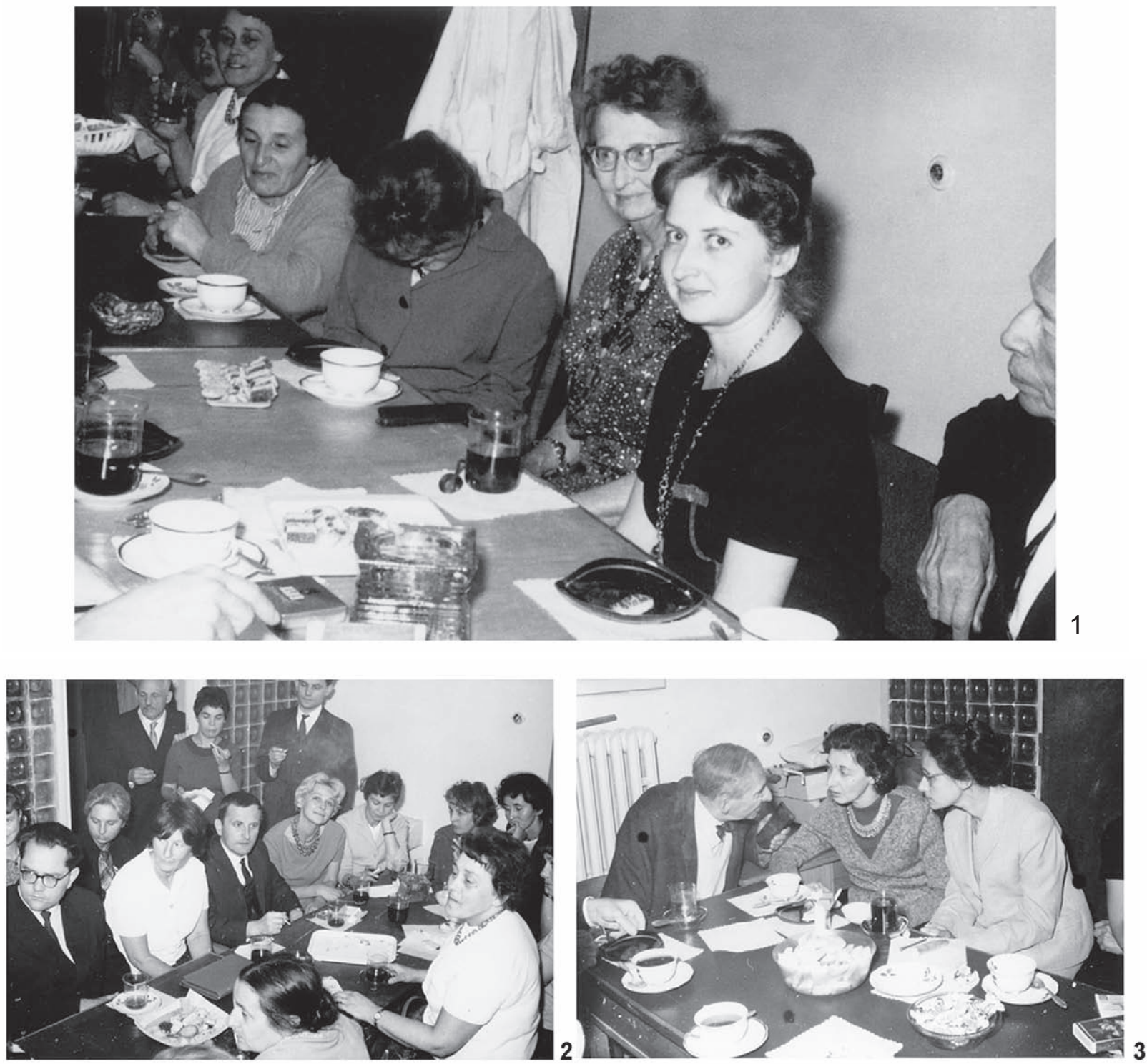

Ryc. 3. I Międzynarodowy Kongres Archeologii Słowiańskiej (Warszawa 14-18 września 1965 r.). Centralne Laboratorium IHKM PAN, Warszawa, dn. 15 (?) września 1965 r., spotkanie archeologów i historyków - badaczy i sympatyków badań nad dawnym szkłem: 1 - od prawej Wicher G.N. van der Sleen

(częściowo widoczny), Maria Dekówna, Maria van der Sleen, Zlata A. Lwowa, Frida D. Gurewicz, Elżbieta Ostrowska; 2 - od lewej, siedzą: Ēvalds S. Mugurewicz, Elżbieta Balcerzak (z tyłu),

Anna Chrzanowska, Jerzy Olczak, Sławomira Ciepiela, Eliza Naumowicz, Alina Urbańska, Aldona Chmielowska (?),

Elżbieta Ostrowska, Frida D. Gurewicz (częściowo widoczna); 3 - od lewej: Stanisław Gebethner, Nino N. Ugrelidze, Ewa Springer. Fot. Stanisław Biniewski

Fig. 3. The $1^{\text {st }}$ International Congress of Slavic Archaeology (Warsaw, $14^{\text {th }}-18^{\text {th }}$ September 1965). Central Laboratory of the Institute for the History of Material Culture of the Polish Academy of Sciences, Warsaw, 15 ${ }^{\text {th }}$ (?) September 1965, meeting of archaeologists and historians - scientists and enthusiasts of the research on historical glass:

1 - from the right: Wicher G.N. van der Sleen (partly visible), Maria Dekówna, Maria van der Sleen, Zlata A. L'vova,

Frida D. Gurevič, Elżbieta Ostrowska; 2 - from the left, sitting: Ēvalds S. Mugurevics, Elżbieta Balcerzak

(in the back row), Anna Chrzanowska, Jerzy Olczak, Sławomira Ciepiela, Eliza Naumowicz, Alina Urbańska,

Aldona Chmielowska (?), Elżbieta Ostrowska, Frida D. Gurevič (partly visible); 3 - from the left:

Stanisław Gebethner, Nino N. Ugrelidze, Ewa Springer. Photo Stanisław Biniewski

szenie Polskiego Komitetu Narodowego, Sekretarz Generalny Stowarzyszenia, prof. dr Joseph Philippe (z Belgii), który m.in. uczestniczył w konferencji zorganizowanej przez Panią Profesor w IHKM PAN (ryc. 4: 1,2; Kamieńska 1966, 730). Badacze polscy przedstawili na niej znaleziska szkieł, datowanych 

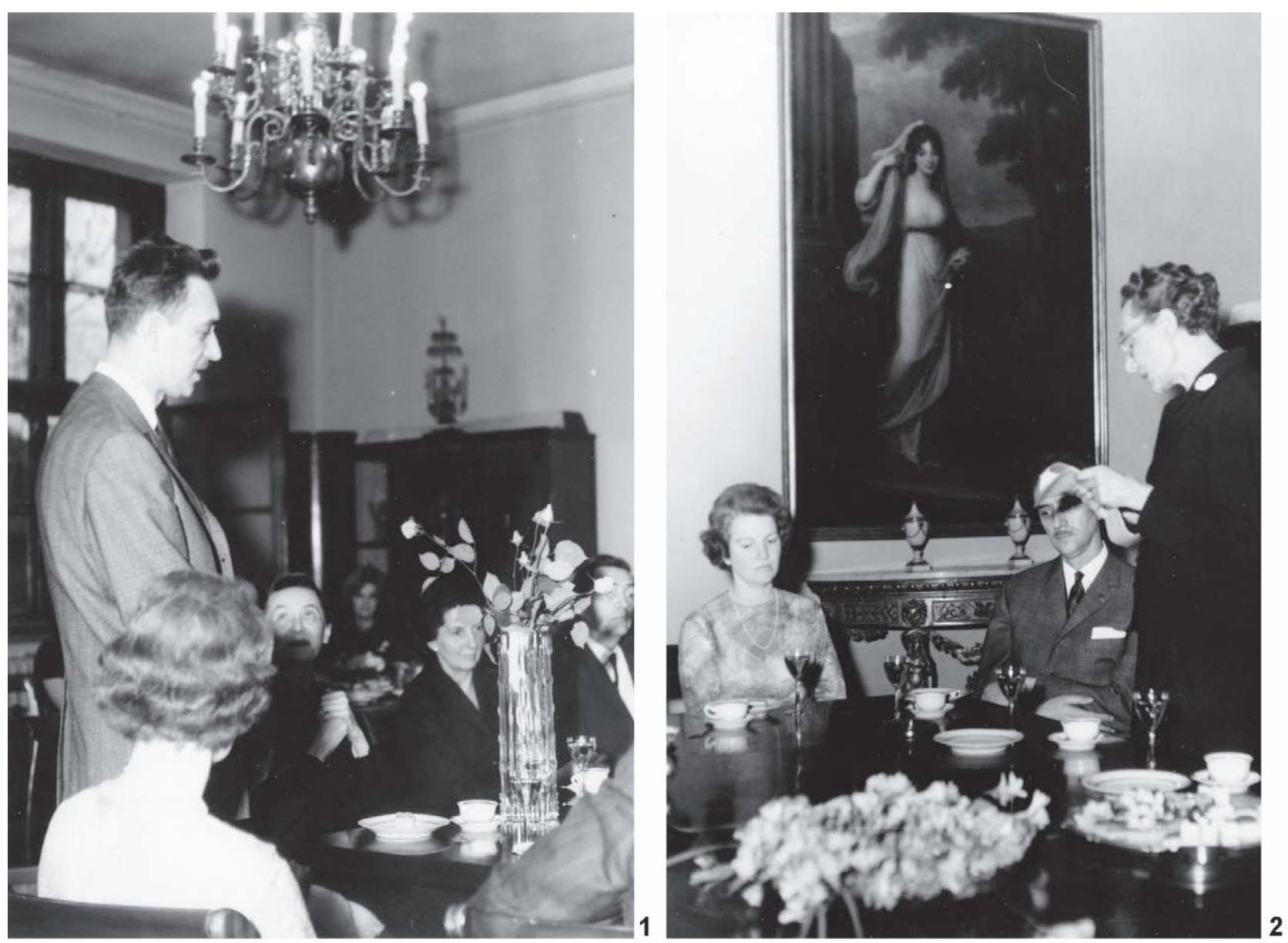

Ryc. 4. Wizyta prof. dra Josepha Philippe’a z małżonka, sekretarza generalnego „Journées Internationales du Verre", w Warszawie. Spotkanie dnia 28 marca 1966 r. w gabinecie prof. dra Stanisława Lorentza w Muzeum Narodowym w Warszawie: 1 - przemawia prof. dr Joseph Philippe, po jego prawej ręce - Pani Raymonde Philippe, po lewej - prof. dr Zofia Kamieńska; 2 - prof. dr Zofia Kamieńska wita gości, naprzeciwko - Pani Raymonde Philippe. Fot. autor nieznany

Fig. 4. The visit of Prof. Dr. Joseph Philippe, the secretary general of "Journées Internationales du Verre", and his wife in Warsaw. The meeting on the $28^{\text {th }}$ of March 1966 in the Prof. Dr. Stanisław Lorentz's office in the National Museum in Warsaw: 1 - Prof. Dr. Joseph Philippe's speech, Mrs. Raymonde Philippe on his right and Prof. Dr. Zofia Kamieńska on his left; 2 - Prof. Dr. Zofia Kamieńska greeting guests, vis-à-vis Mrs. Raymonde Philippe. Photo unknown author

na różne okresy, ujawnione w Polsce. Prof. Philippe stał się odtąd życzliwym ambasadorem polskiego środowiska naukowego w świecie. Na organizowane przez siebie kongresy Stowarzyszenia zawsze zapraszał referentów z Polski, stwarzając dogodne warunki finansowe ich pobytu w miejscach, gdzie te kongresy się odbywały (ryc. 5; Kamieńska 1966, 728-729; Dekówna 2005b, 5).

W latach sześćdziesiątych XX w. powstała obszerna praca poświęcona wczesnośredniowiecznej wytwórczości szklarskiej na terenie Polski. Była to rozprawa doktorska Jerzego Olczaka (1968). Autor, przygotowując ja, wykorzystał wszystkie dostępne wówczas metody badawcze; przeprowadził gruntowną analizę technologiczną, archeologiczną i historyczną zespołów szkieł, w których skład wchodziły pozostałości produkcji. W pracy tej została też po raz pierwszy dokonana wnikliwa interpretacja owych znalezisk obejmująca różne aspekty rozwoju tej gałęzi wytwórczości. W wyniku tych badań Jerzy Olczak stwierdził, że we wczesnym średniowieczu działały w Polsce pracownie szklarskie w kilku ośrodkach: w Wolinie (od 1 poł. X w.), Opolu (na początku XI w.), Kruszwicy (zapewne w 1 poł. XI w.), w lewobrzeżnym Wrocławiu (1 poł. XII w.), na Ostrowie Tumskim we Wrocławiu (na początku 2 poł. XII w.), być może też w Gdańsku (koniec X w.) i w Gnieźnie (1 poł. XI w.). 


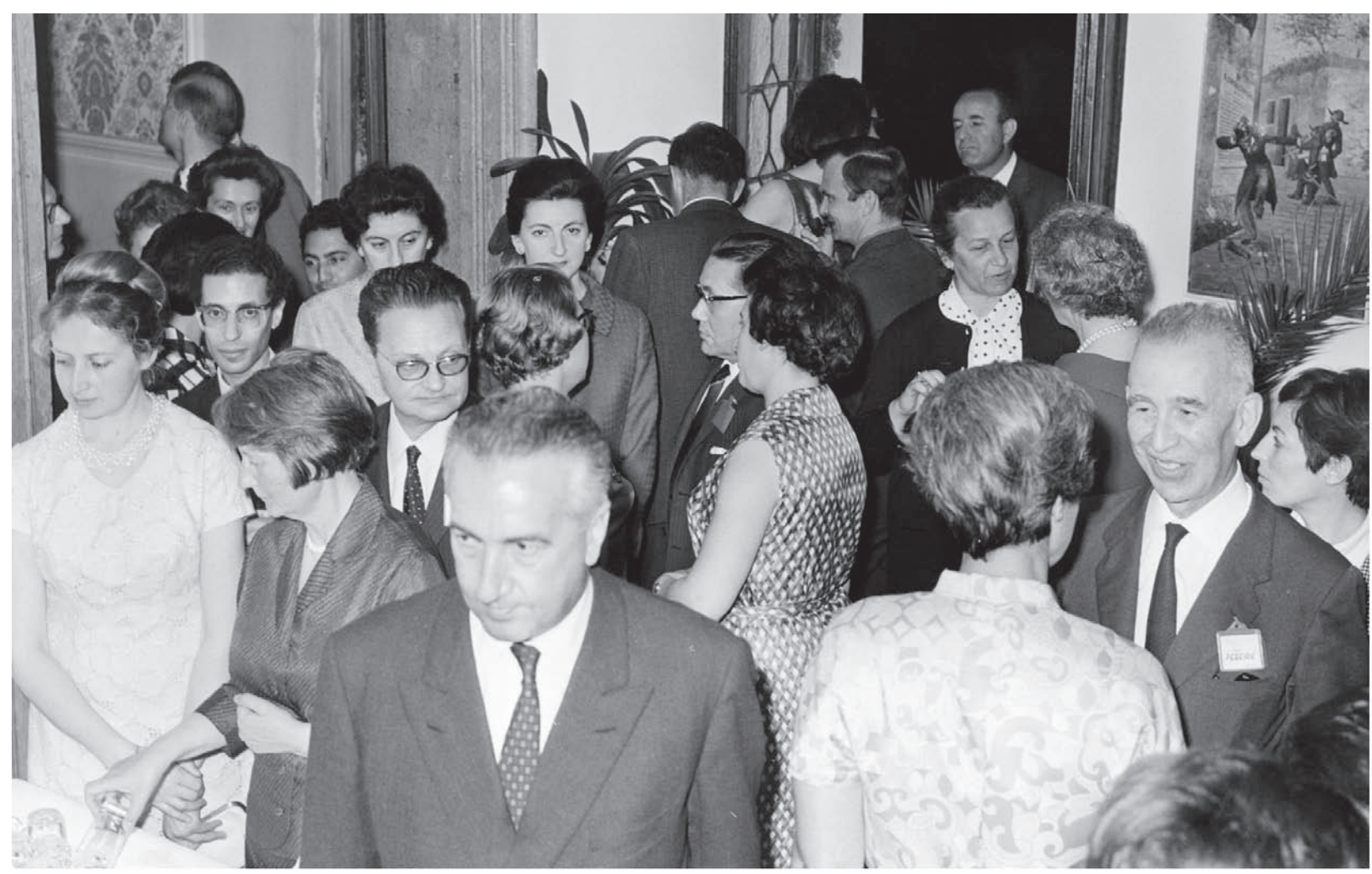

Ryc. 5. IV kongres „Journées Internationales du Verre”, Rawenna-Wenecja 13-20 maja 1967 r.:

Wenecja, 19 maja 1967 r., przyjęcie w Palazzo Martinengo, polskie uczestniczki kongresu, od lewej: Maria Dekówna, po jej lewej ręce Paulina Chrzanowska, z tyłu, w drzwiach, przy framudze - Anna Chrzanowska (częściowo widoczna)

(M. Dekówna 2005b, ryc. 1)

Fig. 5. The $4^{\text {th }}$ Congress of "Journées Internationales du Verre" in Ravenna and Venice, $13^{\text {th }}-20^{\text {th }}$ May 1967 :

Venice, $19^{\text {th }}$ May 1967, banquet in Palazzo Martinengo. Polish participants, from the left: Maria Dekówna, Paulina

Chrzanowska on her left, Anna Chrzanowska in the back (partly visible at the door) (Dekówna 2005b, Fig. 1)

Schyłek lat sześćdziesiątych stanowi pewną cezurę w dziejach badań nad szkłem w Polsce (ryc. 6): kończy się czas tylko inwentaryzowania i dokumentowania źródeł oraz pierwszych prób interdyscyplinarnego do nich podejścia, a zaczyna okres upowszechniania się pogłębionych, wieloaspektowych studiów, często prowadzonych połączonymi metodami różnych dyscyplin naukowych.

\section{LATA SIEDEMDZIESIĄTE XX W. DO PRZEŁOMU XX I XXI W. BADANIA POSTMILLENIJNE. PODSTAWY TEORETYCZNE I METODY BADAŃ. ZNACZNY WZROST LICZBY PUBLIKACJI}

Rośnie wówczas liczba badaczy zajmujących się historią szkła; niektórzy z nich działają w różnych środowiskach, poza Polskim Komitetem Narodowym. Ciagły wzrost liczby znalezisk oraz badań umożliwił, a jednocześnie spowodował konieczność opracowania podstaw teoretycznych i wskazania kierunków tych badań (por. Olczak 1992). W ukazujących się publikacjach, a także na różnych spotkaniach naukowych, zaczęły pojawiać się różne propozycje z tego zakresu (np. Stolpiak 1989; Dekówna 1980, 21-38 - tu przegląd tych metod; Olczak 1984, 52).

Kierując się potrzebą stworzenia jednolitego systemu do opracowywania przedmiotów szklanych różnych kategorii i zróżnicowanych chronologicznie, przedstawiono w 1980 r. plan takich badań (Dekówna 1980, 22-39). Znajduje się tu m.in. propozycja klasyfikacji cech owych przedmiotów, 

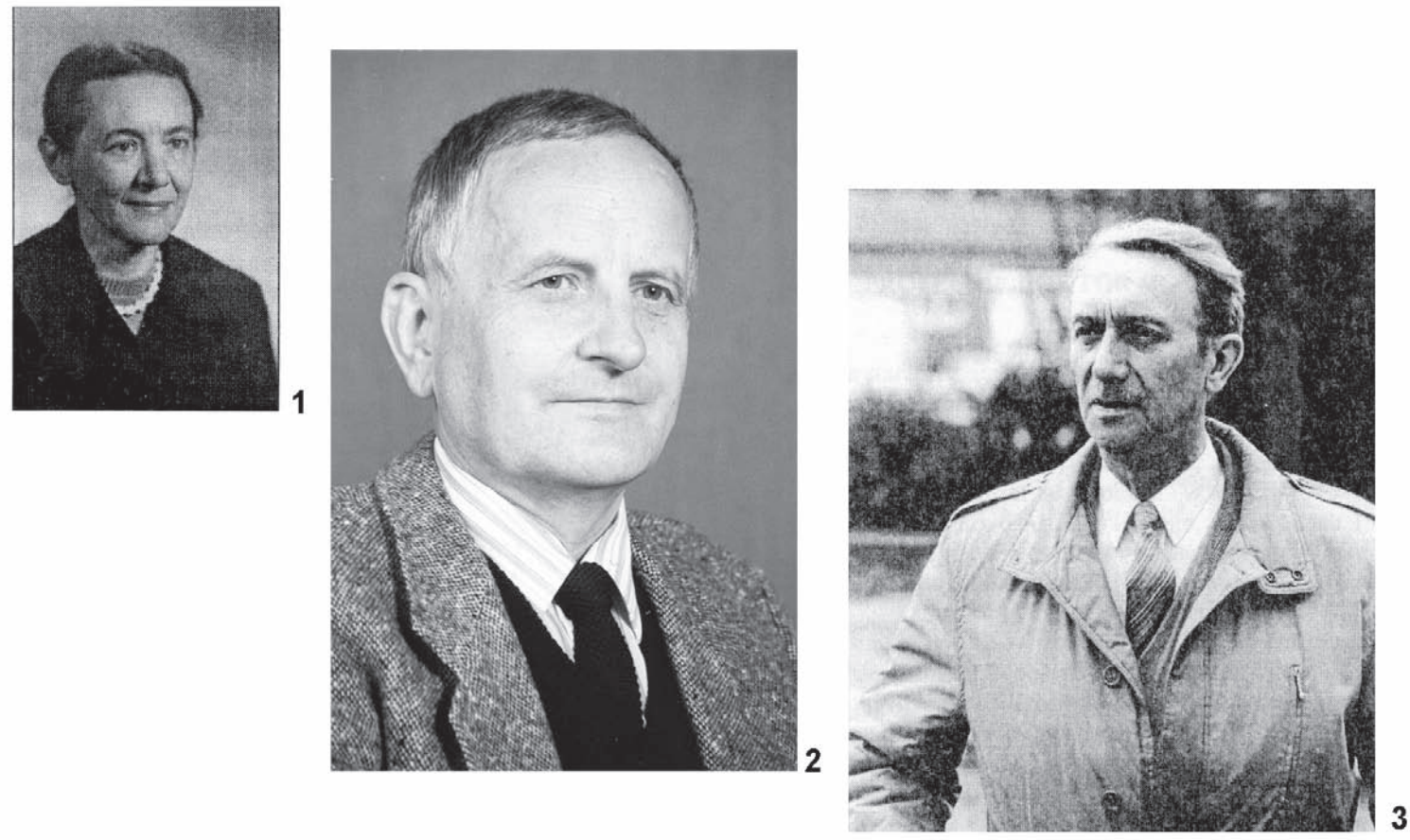

Ryc. 6. Badacze, których wieloletnia działalność przyczyniła się do zainicjowania, a następnie znacznego postępu, badań nad dziejami szkła w Polsce:

1 - prof. dr Zofia Kamieńska (4.06.1908-17.02.1996) inicjatorka i animatorka studiów nad szkłem zabytkowym, organizatorka dużego zespołu badaczy zajmującego się tą problematyką, inicjatorka i redaktor pierwszych dużych publikacji podsumowujących badania prowadzone w latach pięćdziesiątych i sześćdziesiątych XX w.;

2 - prof. dr hab. Jerzy Olczak (31.07.1929-11.05.2007) prekursor badań nad wczesnośredniowiecznym szklarstwem

w Polsce, autor wielu artykułów i monografii zarówno z tej dziedziny, jak i dotyczących szklarstwa okresów późniejszych oraz szklarstwa okresów rzymskiego i wczesnobizantyńskiego w Novae w Bułgarii, inicjator i wieloletni redaktor serii wydawniczej poświęconej dziejom szkła, organizator wielu konferencji naukowych

(w tym międzynarodowych); 3 - prof. dr Joseph Philippe (30.10.1919-28.02.2006), sekretarz generalny (1958-1979),

a następnie przewodniczący (1979-1985) Międzynarodowego Stowarzyszenia do Badań Historii Szkła, pośrednio

przyczynił się do rozwoju studiów nad szkłami zabytkowymi w Polsce i unowocześnienia metod tych badań, umożliwiając polskim pracownikom naukowym kontakty z wybitnymi naukowcami zagranicznymi oraz włączenie się ich w międzynarodowy nurt badań nad tą gałęzią wytwórczości

Fig. 6. Scholars whose long-time activity contributed to initiating and then to a considerable progress in the research on the history of glass in Poland:

1 - Prof. Dr. Zofia Kamieńska (4.06.1908-17.02.1996), the pioneer and driving force of the studies on historical glass, the establisher of a large research team, the initiator and editor of the first meaningful publications summarizing the research projects from the 1950s and the 1960s; 2 - Prof. Dr. Jerzy Olczak (31.07.1929-11.05.2007), the forefather of the research on the early medieval glassmaking in Poland, the author of numerous papers and monographies on glass production both in the Early Middle Ages and the later periods as well as the Roman and early Byzantine glass production

in Novae in Bulgaria, the initiator and long-term editor of a series on the history of glass, the organiser of numerous conferences (including international ones); 3 - Prof. Dr. Joseph Philippe (30.10.1919-28.02.2006), the secretary general (1958-1979) and chairman (1979-1985) of the International Association for the History of Glass who indirectly contributed to a considerable progress in the research on historical glass in Poland and modernizing the research methodology, enabling Polish scholars to get in contact with prominent foreign scientists and therefore letting them become a part of the international research on this branch of production

wskazująca jednocześnie, w jakiej kolejności różne ich cechy powinny być rozpatrywane (ryc. 7: 1). Zdaniem Autorki program taki powinno się zaczynać od studiów nad technologią i techniką szklarską, gdyż te cechy najlepiej określają poziom produkcji oraz pochodzenie badanych przedmiotów
(Dekówna 1980, 32-39). W tym celu, w pierwszym rzędzie należy stworzyć wyspecjalizowane zaplecze laboratoryjne i opracować metody fizykochemiczne dostosowane do badań szkieł zabytkowych (Dekówna 2005b, 10-11, 13, 15-18). 
I. Rodzaj podstawowego składu chemicznego szkła
A. Korpusu
B. Ornamentu

1. Odmiana podstawowego składu chemicznego szkła

$\begin{array}{ll}\text { A. Korpusu } & \text { B. Ornamentu }\end{array}$

1'. Typ chemiczny szkła

$\begin{array}{ll}\Gamma_{1} & \text { B. Ornamentu }\end{array}$

II. Przezroczystość szkła
A. Korpusu
B. Ornamentu

III. Barwa szkła

Chronologia

$\begin{array}{ll}\text { A. Korpusu } & \text { B. Ornamentu }\end{array}$

IV. Technika wykonania przedmiotu

1. Podstawowa

2. Uzupełniająca

$\stackrel{1}{\text { A. Korpusu }}$ B. Technika wykonania ornamentu

V. Rodzaj przedmiotu

VI. Forma

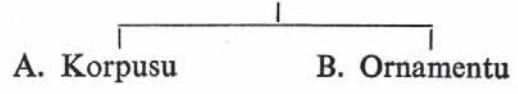

1. Kategoria znaleziska

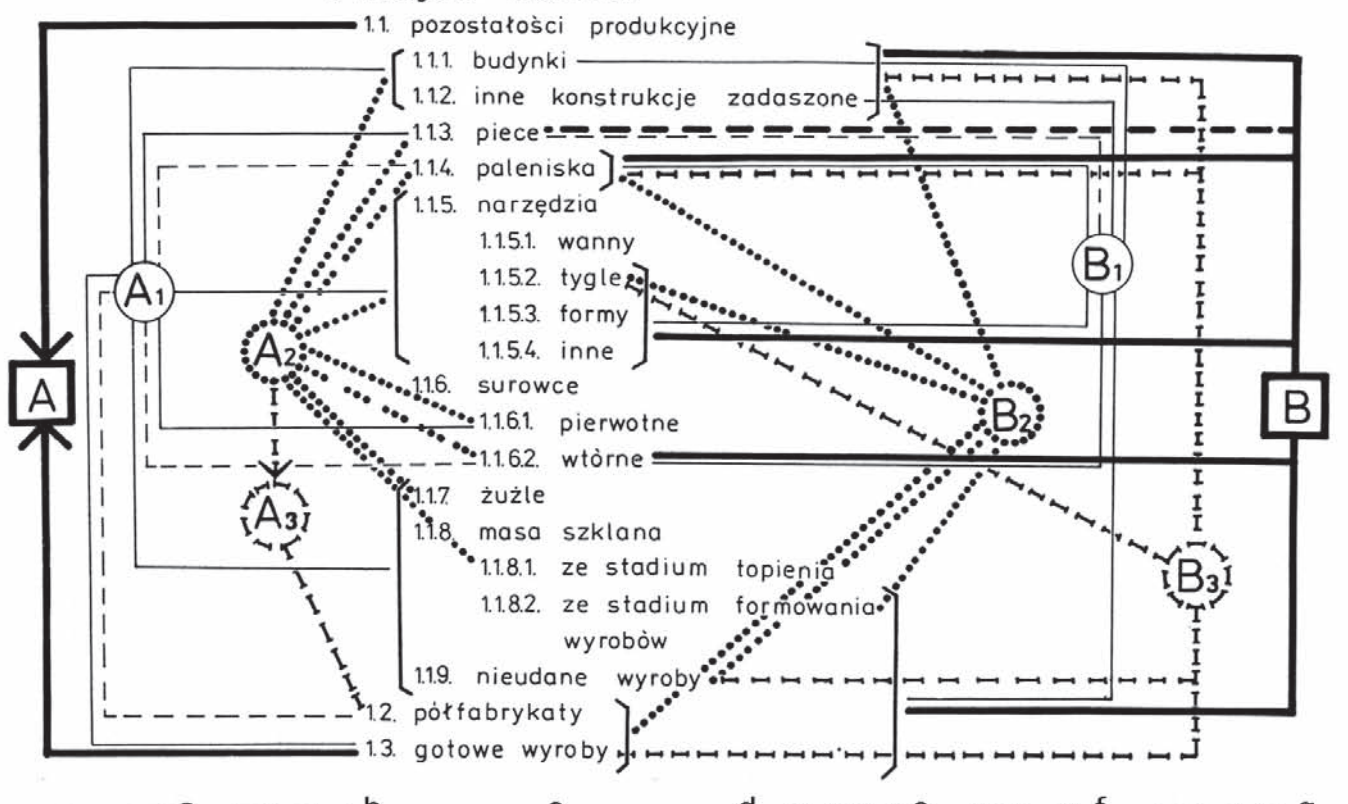

$\longrightarrow a--b$ c

- d

e $\mathrm{e} \ldots \ldots f$

$\mapsto \mapsto \mapsto \mapsto \mathrm{g}$

$A$ A $A_{1}{ }_{i}$ 
W latach sześćdziesiątych XX w. w Centralnym Laboratorium IHKM w Warszawie została wprowadzona, stosowana do lat dziewięćdziesiątych ubiegłego wieku, metoda ilościowej analizy spektralnej; od 1967 r. została oparta na wzorcach, które przygotowali pracownicy Instytutu Przemysłu Szkła i Ceramiki w Warszawie (Dekówna 1980, 7; 2005b, 15). Za jej pomocą przebadano skład chemiczny szkła kilku tysięcy zabytków. Jednak analiza szkła i jej rezultaty są pierwszym etapem poznania technologii szkieł zabytkowych. Wynik analizy pozwala tylko na ogólną orientację w tym zakresie, która jest niewystarczająca do rozwiązania podstawowego celu tych badań, jakim jest odtworzenie całokształtu produkcji i dystrybucji wyrobów szklanych na danym obszarze. Aby mógł on dostarczyć pełnych i dokładnych informacji, musi być poddany dalszym zabiegom badawczym. Są nimi m.in. metody klasyfikacji i interpretacji wyników analizy składu chemicznego (Dekówna 1980, 2932; 1990, 16-25). Próbę taką opublikowała między innymi Julia Szczapowa, która określiła zawartości graniczne głównych składników szkłotwórczych, a także proporcje i sumy tych ostatnich (Szczapowa 1973; 1975; 1983, 26-33). Na tej podstawie można wyróżniać rodzaje, odmiany i typy chemiczne szkieł oraz określać poziom technologiczny, a następnie pochodzenie badanych przedmiotów. Schemat ten został następnie uzupełniony (tabela 1) przez Marię Dekównę (1975, 183-186; 1990, 16-25, 27-31) i Teresę Stawiarską (1984, tabele 4-6).

W końcu lat sześćdziesiątych XX w. w Centralnym Laboratorium IHKM zaczęto wykonywać szlify petrograficzne szkieł; umożliwiło to dokładniejsze określanie techniki produkcji przede wszystkim biżuterii szklanej (Dekówna, Szymański 1971).
Stworzenie aparatu badawczego, a także pojawienie się nowych znalezisk, pozwoliło na powtórne przeanalizowanie wczesnośredniowiecznych zespołów produkcyjnych. Na tej podstawie M. Dekówna sformułowała hipotezę, że we wczesnośredniowiecznej Polsce funkcjonowały przede wszystkim pracownie przetwórcze, przerabiające stłuczkę szklaną lub korzystające $\mathrm{z}$ półfabrykatów przywożonych z innych ośrodków ( $\mathrm{z}$ innych obszarów) (Dekówna 1974; 1988). Należały do nich pracownie w: Wolinie, Kruszwicy, Opolu, Niemczy, na Ostrowiu Tumskim we Wrocławiu oraz w Szczecinie (gdzie odkryto pracownię tego typu z 4 ćw. IX-1 poł. X w.). Jedynie na terenie lewobrzeżnego Wrocławia funkcjonowały huty wytapiające szkło z surowców wyjściowych (Dekówna 1980, 239 nn.; 1992).

W wyniku opracowanej przez tę badaczkę klasyfikacji pozostałości produkcyjnych można było skonstruować schemat obrazujący związek kategorii znalezisk związanych ze szklarstwem z różnymi odmianami warsztatów szklarskich (ryc. 7: 2; Dekówna 1988; por. też Callmer 1987).

Kolejną kwestią są metody opisu źródeł dotyczących szklarstwa. Próby ujednolicenia tych metod były publikowane przez różnych badaczy polskich i zagranicznych (ich przegląd zob. m.in. Dekówna 1980, 21-38; 2005b). Z inicjatywy polskiej szeroko zakrojone studia $\mathrm{w}$ tym zakresie prowadzono, począwszy od 1970 r. (ich wyniki opublikowano w 2002 r.), w większym zespole międzynarodowym. Na podstawie bogatych materiałów zabytkowych $\mathrm{z}$ terenu Polski, Europy wschodniej, południowo-wschodniej i Zakaukazia, datowanych na czasy od epoki brązu po średniowiecze, opracowano rozbudowane schematy

Na sąsiedniej stronie:

Ryc. 7. Schematy: klasyfikacji źródeł dotyczących szklarstwa (1) oraz obrazujący związek kategorii znalezisk dotyczących szklarstwa z różnymi odmianami warsztatów szklarskich (2): a, h - warsztatów typu A z elementami typu B: c, i; e, j; g, k - warsztatów odmian typu A ( $\left.\mathrm{A}_{1}, \mathrm{~A}_{2}, \mathrm{~A}_{3}\right)$; a , 1- warsztatów typu B: c, m; e, n; g, o - warsztatów odmian typu $\mathrm{B}\left(\mathrm{B}_{1}, \mathrm{~B}_{2}, \mathrm{~B}_{3}\right)$. Symbolami przerywanymi (b, d, f) oznaczono prawdopodobną przynależność znalezisk danej kategorii, podkategorii lub grupy znalezisk do określonej odmiany warsztatów

(Dekówna 1980, 33-34 [1]; 1988, ryc. 6 [2])

Fig. 7. Diagrams of classification of sources related to glassmaking (1) and illustrating the relationship between the category of glass-related finds and different types of glassworks (2): a, h-Type A glassworks with the elements of Type B: c, i; e, j; g, k - variants of Type A glassworks (A1, A2, A3); a, 1- Type B glassworks:

c, m; e, n; g, o - variants of Type B glassworks (B1, B2, B3). Dotted symbols (b, d, f) mark possible connection of the finds of a particular category, subcategory or a group of finds with a specific type of glasswork

(Dekówna 1980, 33-34 [1]; 1988, Fig. 6 [2]) 
Paciorek nr inw. E469/4 (ryc. 3.5.9d; 3.5.17: E469/4).

Stan zachowania przedmiotu: osnowy - cały; ornamentu - cały (szkło dwóch z rombów nie jest zachowane w całości; pod lupą widać, że krawędzie [ścianki] rombów są regularne, ale szkło ornamentu nie pokrywa w całości ich zarysów, a w miejscu, gdzie go nie ma, jest płytki negatyw); Forma: (osnowa) - paciorek z jednym korpusem, bez szyjek; kształt ogólny korpusu - graniastosłup z lekko zaokrąglonymi narożnikami (jedna ze ścianek jest wgnieciona [lekko wklęsła]); kanalik jeden - lekko decentryczny - nierównoległy; krawędź kanalika - pierwsza (A) - zaokrąglona dwustronnie; krawędź kanalika - druga (B) - zaokrąglona dwustronnie; kształt ogólny kanalika - stożkowy, ze ściętym wierzchołkiem; Forma: (ornament) - miejsce rozmieszczenia - na powierzchni zewnętrznej - miejscami - na korpusie - w części środkowej (około połowy wysokości paciorka lub nieco powyżej; ornament nie wchodzi na powierzchnie przyotworowe); elementy ornamentu - 4 romby (po jednym na każdej ze ścianek paciorka) - nie przecinające się - których dłuższe osie ułożone są równolegle (3 romby) lub skośnie (1 romb) w stosunku do kanalika; wygląd ornamentu - plaski; materiał - srebro; Wymiary: osnowa - D (średnica): 0,56-0,59 cm; H (wysokosć): 0,85-0,91 cm; R (szerokosć) boków: 0,56 cm, 0,57 cm, 0,59 cm, 0,57 cm; kanalik - D (średnica A): 0,39_0,41 cm; D (średnica B): 0,32-0,34 cm; ornament - $\mathrm{R}$ (szerokość) $\times \mathrm{H}$ (wysokość 1 rombu): 0,27 × 0,47 cm; $\mathrm{R}$ (szerokosć) $\times \mathrm{H}$ (wysokość 2 rombu): $0,26 \times 0,48 \mathrm{~cm} ; \mathrm{R}$ (szerokośc) $\times \mathrm{H}$ (wysokosć 3 rombu): $0,29 \times 0,49 \mathrm{~cm} ; \mathrm{R}$ (szerokość) $\times \mathrm{H}$ (wysokość 4 rombu): 0,29 × 0,55 cm; Ślady zabiegów technicznych: rozmieszczenie masy szklanej - równomierne - koncentryczne lub spiralne w stosunku do kanalika; wygląd powierzchni wewnętrznej (tj. kanalika) - całej - matowa - chropowata; ślady na powierzchni zewnętrznej - rysy ułożone na całej powierzchni zewnętrznej spiralnie lub faliście w stosunku do kanalika (rysy pokrywają szkło osnowy i wchodzą pod ornament; w najszersze rysy wtopiło się bardzo cienkie tworzywo ornamentu, co sprawia mylne wrażenie, że rysy pokrywają też dekorację); na jednym boku ornamentowanym wzdłużne znaczne wgłębienie prawie na całej szerokości boku; ślady wewnątrz szkła - wtrącenia gazowe - pęcherze - występujące miejscami - okrągłe (osnowa i ornament) i elipsoidalne (osnowa) - bezładne i koncentryczne, spiralne lub podłużne w stosunku do kanalika (pojedynczy pęcherz elipsoidalny [około $0,15 \mathrm{~cm}$ długości ] znajduje się poniżej powierzchni przyotworowej B i ułożony jest lekko spiralnie; większy pęcherz [0,23 cm długości] znajduje się około połowy wysokości paciorka przy krawędzi dwóch ścianek i ułożony jest podłużnie; w szkle widać jeszcze wiele mniejszych pęcherzy ułożonych spiralnie, koncentrycznie lub podłużnie w stosunku do kanalika); Technika wykonania osnowy: sposób formowania - nawijanie; technika uzupełniająca - spłaszczenie boków (nadanie paciorkowi kształtu graniastosłupa); Technika wykonania ornamentu: sposób wykonania ornamentu - oddzielnie od osnowy - na wyrobie - nakładanie elementów ornamentu (tj. 4 rombów), malowanie? (być może zawiesiną sproszkowanego srebra i wody, jak w przypadku paciorków nry E440 i 447/2 z grobu E877; zob. ryc. 3.5.8b-d i 3.5.17: 469/4, gdzie widoczne są koliste elementy w strukturze jednego $z$ rombów); Stan zachowania szkła: stan zachowania osnowy - dobry; wygląd powierzchni zewnętrznej - całej - błyszcząca - gładka; stan zachowania ornamentu - dobry; wygląd powierzchni zewnętrznej - całej - matowa - gładka i lekko chropowata; Wady masy szklanej: miejsce występowania - w osnowie - wtrącenia gazowe - pęcherze - miejscami - liczne - małe i duże - zamknięte i otwarte; Wyniki analizy składu chemicznego szkła: EPMA - badania przeprowadzone przez dr. Piotra Dzierżanowskiego; wynik analizy nie zamieszczony w niniejszej pracy; Typ chemiczny szkła: osnowy - $\mathrm{Na}$ bieskie (pomiędzy 16.3 a 16.4); ornament - żóltozielone (zbliżone do 11.7); Barwniki: osnowa - $\mathrm{Fe}_{2} \mathrm{O}_{3}$; Odbarwiacze: osnowa - MnO; Przezroczystość szkła: osnowa - wyraźnie przejrzyste; Srodki mącące: osnowa -.

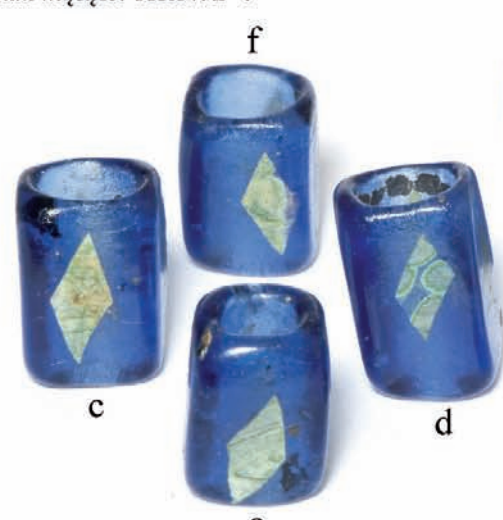

a

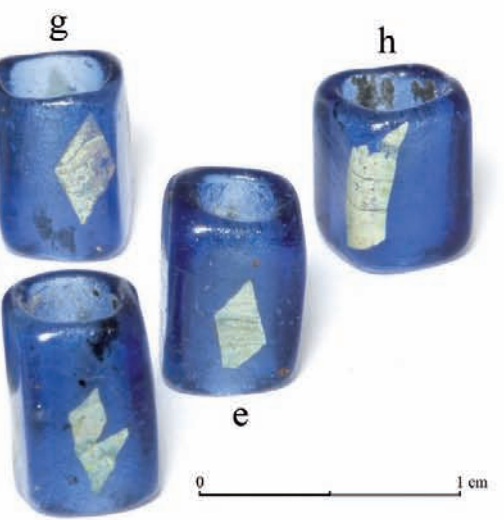

b

Ryc. 8. Przykład opisu paciorka szklanego zdobionego srebrnymi rombami, z wczesnośredniowiecznego cmentarzyska w Bodzi, gm. Lubanie, woj. kujawsko-pomorskie, według zasad opublikowanych w Principes... 2002

(Dekówna, Purowski 2016, ryc. 3.5.9 oraz płyta CD, s. 48)

Fig. 8. A description example of a glass bead decorated with silver rhombi from the early medieval cemetery in Bodzia, Lubanie community, kujawsko-pomorskie vivodeship, according to the rules published in Principes... 2002

(Dekówna, Purowski 2016, Fig. 3.5.9 with a CD, p. 48) 


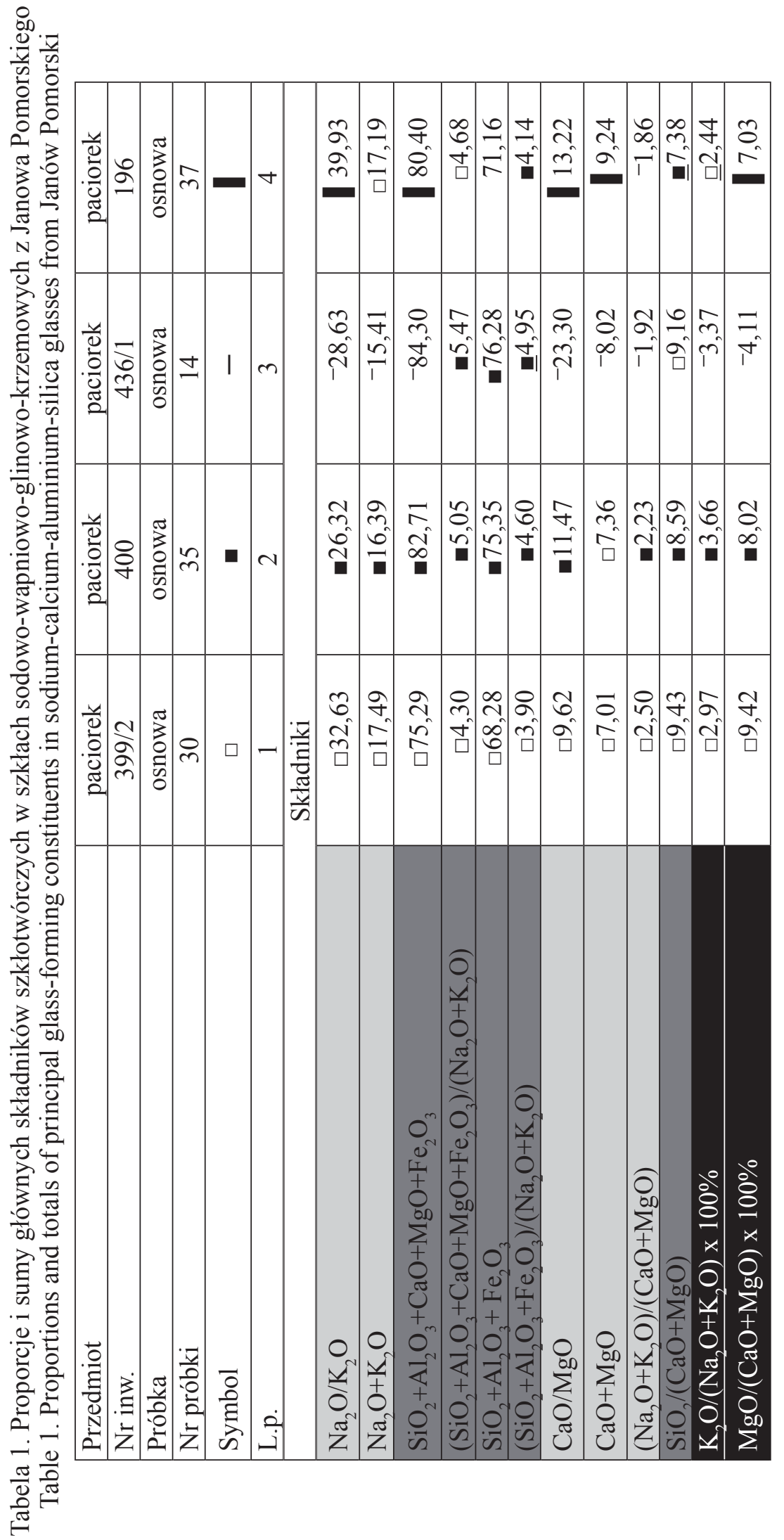

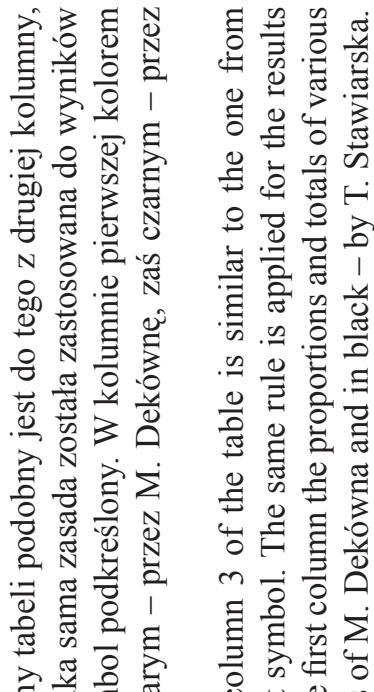

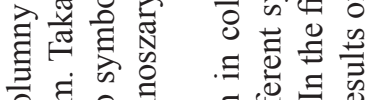

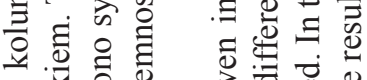
ब.

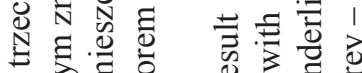

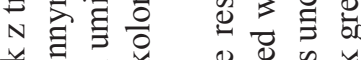

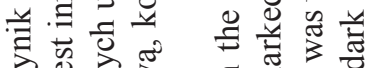

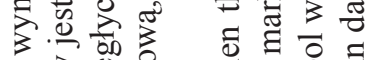

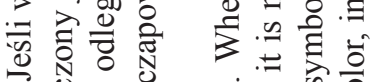

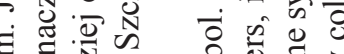
हี่

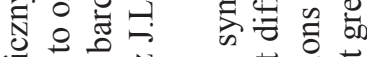

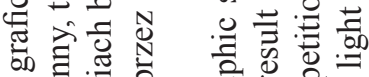

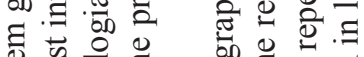

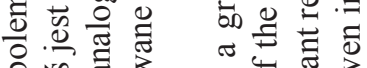

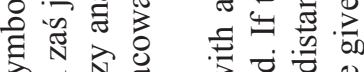

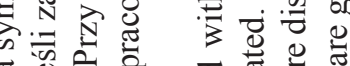

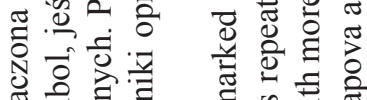

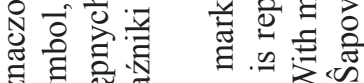
तิ पू छ छ 品 步

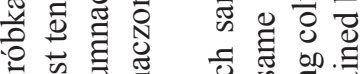

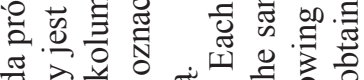

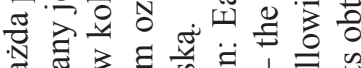

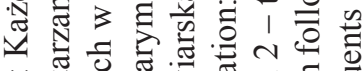

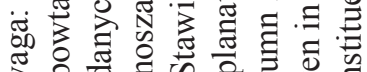

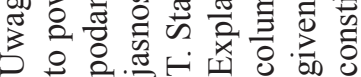

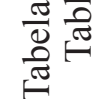


opisu przedmiotów szklanych wielu kategorii, w których zostały uwzględnione różne cechy tych przedmiotów (formalne, technologiczne) (ryc. 8; Principes... 2002).

Przedstawione wyżej działania przyczyniły się do powstania nowej dyscypliny naukowej: historii szklarstwa. Wypracowanie właściwego dla niej zespołu metod (składającego się z dostosowanych do jej celów badawczych głównie metod nauk humanistycznych i fizykochemicznych) pozwoliło na znaczne poszerzenie wiedzy o historii produkcji szklarskiej i wyrobach szklanych na naszych ziemiach. Okazał się on przydatny do badań nie tylko nad szkłami wczesnośredniowiecznymi (do których jest najczęściej wykorzystywany), ale też nad szkłami z innych epok (epoki brązu i wczesnej epoki żelaza - np. Stolpiak 1988; Purowski 2012; okresu rzymskiego - np. Olczak 1998) ${ }^{4}$.
W omawianym okresie znacznie wzrosła liczba różnego rodzaju publikacji (artykułów, monografii, syntez). Ich tematem są nie tylko znaleziska z terenu Polski, ale także ujawnione na innych obszarach, do których opracowania byli zapraszani badacze polscy (np. Dekówna 1975; 1990; 1996; Olczak 1998; Tabaczyńska 1977; krótki przegląd opracowań szkieł odkrytych na terenach pozapolskich - zob. Dekówna 2005b). Zaczęła się również wypełniać luka badawcza dotycząca szkieł pradziejowych: pojawily się obszerne opracowania poświęcone tym szkłom (np. Karwowski 1997; Purowski 2007), które w poprzednich okresach cieszyły się niewielkim zainteresowaniem badaczy. Wyraźny postęp w zakresie stanu badań i wiedzy widoczny jest też w odniesieniu do szkieł z następnych okresów: wpływów rzymskich, wczesno- i późnośredniowiecznego (Dekówna 2005a, 225-226).

\section{POCZĄTEK XXI W. SYTUACJA W OKRESIE DRUGIEJ ROCZNICY MILLENIJNEJ (1050-EJ). ODMŁODZENIE KADRY NAUKOWEJ. STABILIZACJA W ZAKRESIE METODOLOGII}

Zmienione warunki funkcjonowania nauki w Polsce mają oczywiście wpływ na rozwój badań nad problematyką omawianą $\mathrm{w}$ niniejszym artykule. Wycofywanie się z finansowania tych badań przez macierzyste instytucje (które w poprzednich okresach były najczęściej jedynymi ich sponsorami) zaangażowanych $\mathrm{w}$ nie pracowników naukowych i uzależnienie owych badań od środków zewnętrznych (grantów), których napływ lub jego brak, nierzadko przypadkowy, będący wynikiem decyzji (w tym negatywnych) osób niezwiązanych profesjonalnie $\mathrm{z}$ tematyką zgłaszanych prac, opartych na kryteriach formalnych, a nie merytorycznych, utrudnia podejmowanie dhugofalowych inicjatyw, formułowanie wieloletnich planów badawczych, zwłaszcza dotyczących rozległej zarówno pod względem chronologicznym, jak i tematycznym, problematyki ${ }^{5}$ oraz kształtowanie na bieżąco

4 Znaczenie metod interpretacji wyników analiz składu chemicznego dawnego szkła dla badań nad szkłami z okresu wpływów rzymskich rozpatrywała T. Stawiarska (1987a; 1987b).

5 Na przykład wniosek o sfinansowanie opracowania syntezy dziejów szkła na ziemiach polskich od epoki brązu do późnego średniowiecza, z którym wystąpiło w marcu zespołów badawczych w czasie prowadzenia studiów, w zależności od potrzeb pojawiających się w ich trakcie. Lecz nierzadko, zwłaszcza w przypadku badań o mniejszym zasięgu czasowym i merytorycznym, system ten sprzyja podejmowaniu takich prac.

Polski Komitet Narodowy Międzynarodowego Stowarzyszenia do Badań Historii Szkła działa nadal (obecnie jest afiliowany przy Instytucie Archeologii i Etnologii Polskiej Akademii Nauk w Warszawie; dalej: IAE PAN), ale nie może realizować własnych projektów ze względu na brak funduszy. Jego działalność ogranicza się do organizowania periodycznych zebrań, na których przedstawiane są wyniki najnowszych badań nad dziejami szkła, wymieniane informacje o różnych wydarzeniach naukowych inicjowanych w Polsce i za granica, publikacjach, konferencjach. W dalszym ciagu jednak odgrywa ważną rolę $\mathrm{w}$ integrowaniu środowiska oraz rolę inspiratora i promotora studiów prowa-

2012 r. grono dziesięciu badaczy z różnych placówek naukowych w Polsce, nie zyskał aprobaty decydentów. Podobnie zakończyły się wnioski dotyczące innych dużych projektów. 
dzonych przez polskich badaczy i placówki naukowe, a także propagatora ich osiagnięć.

Ciężar badań naukowych przeniósł się w omawianym okresie na studia indywidualne lub prowadzone w małych zespołach, w których najczęściej uczestniczą oprócz archeologów także chemicy lub przedstawiciele innych nauk ścisłych. Obserwujemy przy tym bardzo pozytywne zjawisko: zainteresowanie się dziejami szkła przez sporą grupe młodych adeptów archeologii; wielu z nich realizuje te zainteresowania, przygotowując rozprawy doktorskie. Ich tematyka obejmuje przede wszystkim szkła z okresów: rzymskiego z terenów pozapolskich (głównie z obszarów nadśródziemnomorskich) oraz wczesnośredniowiecznego - szkła odkryte na naszych ziemiach. Nadal widać znaczny postęp w badaniach nad szkłami pradziejowymi ujawnionymi na obszarze Polski; zawdzięczamy go studiom doktora Tomasza Purowskiego, który wraz ze specjalistami reprezentującymi dyscypliny fizykochemiczne opracowuje kolejne tematy dotyczące szkieł z epoki brązu i wczesnych okresów epoki żelaza, publikując wyniki swoich badań na łamach czasopism polskich i zagranicznych (np. Purowski et al. 2012; Purowski et al. 2016). Kontynuowane są też studia nad szkłami z okresu lateńskiego (np. Karwowski 2012; Purowski, Wagner 2015).

Jednak najwięcej badaczy młodego pokolenia koncentruje się na studiach nad szkłami wczesnośredniowiecznymi. Pod względem różnorodnej aktywności naukowej wyróżnia się zwłaszcza ośrodek wrocławski, gdzie dr Aleksandra Pankiewicz, mgr Sylwia Siemianowska i dr Krzysztof Sadowski (pochodzący z różnych placówek naukowych tego miasta) w ramach uzyskiwanych grantów doprowadzili do przeanalizowania składu chemicznego szkła znacznej liczby przedmiotów odkrytych na terenie czołowych grodów śląskich (Wrocławia, Opola, Niemczy i innych). Wyniki swoich badań wspomniany zespół sukcesywnie publikuje (np. Siemianowska 2015; Pankiewicz et al. 2017) ${ }^{6}$. We Wrocławiu odbywają się, dzięki znacznemu udzia-

6 Za informacje o przedsięwzięciach naukowych podejmowanych przez wymieniony zespół dziękuję Pani mgr Sylwii Siemianowskiej. Wcześniej, w monografii poświęconej późnośredniowiecznym naczyniom szklanym na Śląsku, stan badań nad wytwórczością szklarską we wczesnym średniowieczu w tym rejonie omówiła krótko Jadwiga Biszkont (2005, 9-15). łowi organizacyjnemu mgr Sylwii Siemianowskiej, mgra Krystiana Chrzana i dra Pawła Rzeźnika, duże międzynarodowe sympozja, których tematyka dotyczy szklarstwa i ceramiki różnych okresów i różnych regionów europejskich ${ }^{7}$. Szkła z wszystkich stanowisk w Wolinie są przedmiotem przyszłej pracy doktorskiej mgr Karoliny Kokory ze Szczecina, a mgr Sylwia Wajda z Warszawy opracowała i opublikowała szkła z niektórych stanowisk z Polski środkowej i wschodniej (np. Wajda 2014).

W omawianym okresie stosowane są w większym (Dekówna, Purowski 2012; 2016; Kokora 2016) lub mniejszym stopniu metody opracowane w ostatnim trzydziestoleciu ubiegłego stulecia. Jedynie w odniesieniu do szkieł z epoki brązu i okresu halsztackiego znalezionych na terenie Polski odnotowujemy przenoszenie do polskiej praktyki badawczej nowych kryteriów interpretacji wyników analiz składu chemicznego zaproponowanych przez niektórych naukowców zachodnioeuropejskich do badania znalezisk z tych właśnie okresów (por. różne prace T. Purowskiego).

Realizowane w ciaggu ostatnich kilku lat wspomniane wyżej nowe interdyscyplinarne studia nad całokształtem zbiorów znalezisk związanych ze szklarstwem z wymienionych wyżej stanowisk śląskich i wolińskich (ujawnionych $\mathrm{w}$ wyniku prac wykopaliskowych prowadzonych w czasie przygotowywania obchodów tysiąclecia Państwa Polskiego jak i późniejszych - z tych ostatnich wiele nie było dotychczas publikowanych) zapewne dostarczą przesłanek, które pozwolą zweryfikować dotychczasowe poglądy na temat wczesnośredniowiecznego szklarstwa w Polsce: jego genezy, poziomu technologicznego, struktury organizacyjnej oraz pochodzenia i kierunków napływu na nasze ziemie wyrobów szklanych, półfabrykatów, surowców, technologii. Szkoda, że nie znalazły się wśród nich materiały z Kruszwicy - legendarnego symbolu początków polskiego szklarstwa.

7 Sympozja te, pod ogólnym tytułem Międzynarodowe Sympozjum Ceramiki i Szkła OSTRAKON organizowane są (w latach 2014, 2015 i 2017) przez Ośrodek Badań nad Kulturą Późnego Antyku i Wczesnego Średniowiecza IAE PAN oraz Katedrę Konserwacji i Restauracji Ceramiki i Szkła Akademii Sztuk Pięknych im. E. Gepperta we Wrocławiu. Każde sympozjum poświęcone jest innej problematyce z tego zakresu (por. Pankiewicz \& al. 2017, s. 17, przyp. 7). 
Wśród pojawiających się w tym czasie publikacji znajdują się też opracowania szkieł, datowanych na różne okresy, odkrytych na obszarach pozapolskich autorstwa badaczy polskich (np. Dekówna [2010] 2015; Dekówna, Dymaczewska 2015; Karwowski 2004; Kucharczyk 2011; Kunicki-Goldfinger etal. 2014; Stawiarska 2014; Żuchowska 2016). Sporadycznie natomiast podejmowano wspólne prace $\mathrm{z}$ badaczami zagranicznymi.

Niepokoi zanikający udział polskich pracowników naukowych w zagranicznych kongresach, konferencjach i innych tego typu spotkaniach. Dorobek polskiego środowiska naukowego udostępniany jest więc przede wszystkim przez Polski Komitet Narodowy Międzynarodowego Stowarzyszenia do Badań Historii Szkła, który systematycznie wysyła książki i artykuły autorów polskich do biblioteki Corning Museum of Glass w Nowym Jorku (centralnej biblioteki gromadzącej publikacje poświęcone problematyce szklarskiej z całego świata) oraz wykazy tych prac do kierownictwa Stowarzyszenia, dzięki czemu informacje o nich znajdują się w biuletynach tej organizacji rozsyłanych do członków Stowarzyszenia i placówek naukowych działających na różnych kontynentach.

Zwraca uwagę fakt, że pomimo wspomnianych ograniczeń omawiany krótki okres, bo obejmujący tylko kilkanaście lat, obfituje jednak w nowe ważne inicjatywy, z których część będzie finalizowana w latach następnych, i których wyniki zapewne wniosą nowe elementy do naszej wiedzy o dziejach szkła na ziemiach polskich.

\section{BIBLIOGRAFIA}

Abramowicz A. 2005 (rec.). Bartłomiej Noszczak, „Sacrum” czy „profanum”? Spór o istotę obchodów milenium polskiego (1949-1966). Archeologia Polski 50 (1-2), 194-201.

Biezborodow M.A., Olczak J. 1964. Chemiczno-technologiczna i petrograficzna charakterystyka domniemanego surowca szklarskiego z wczesnośredniowiecznej Kruszwicy. Slavia Antiqua 11, 361-374.

Biszkont J. 2005. Późnośredniowieczne szklarstwo na Śląsku. Wratislavia Antiqua. Studia do dziejów Wrocławia 7. Wrocław.

Callmer J. 1987. Pragmatic notes on the early medieval beadmaterial in Scandinavia and the Baltic region ca. A.D. 600-1000. (W:) G. Labuda, S. Tabaczyński (red.), Studia nad etnogenezq Stowian i kultura Europy wczesnośredniowiecznej 1. Wrocław-WarszawaKraków-Gdańsk-Łódź, 217-226.

Cofta A. 1954. Badania archeologiczne w Kruszwicy w 1953 r. Przeglad Zachodni 10 (1-2), 224-231.

Cofta A. 1955. Sprawozdanie z prac wykopaliskowych w Kruszwicy w latach 1953 i 1954. Sprawozdania Archeologiczne 1, 91-104.

Dekówna M. 1974. Au sujet de l'existence à l'époque du haut Moyen Âge d'ateliers de transformation du verre dans les pays slaves. Archaeologia Polona 15, $305-$ 312.

Dekówna M. 1975. Wyroby szklane z grodziska w Styrmen (Bułgaria). Slavia Antiqua 22, 177-277.

Dekówna M. 1980. Szkło w Europie wczesnośredniowiecznej. Wrocław-Warszawa-Kraków-Gdańsk.
Dekówna M. 1988. Uwagi na temat klasyfikacji i interpretacji pozostałości starożytnej i wczesnośredniowiecznej produkcji szklarskiej. (W:) G. Labuda, S. Tabaczyński (red.), Studia nad etnogeneza Stowian i kultura Europy wczesnośredniowiecznej 2. Wrocław-WarszawaKraków-Gdańsk-Łódź, 5-20.

Dekówna M. 1990. Untersuchungen an Glasfunden aus Haithabu. Berichte über die Ausgrabungen in Haithabu 27. Neumünster, 9-63.

Dekówna M. 1992. Produkcja i obróbka szkła (do XV wieku). (W:) B. Orłowski (red.), Z dziejów techniki $w$ dawnej Polsce. Warszawa, 379-410.

Dekówna M. 1996. Szkło okienne z fortu rzymskiego w Gelligaer w południowej Walii. Acta Universitatis Nicolai Copernici. Archeologia 26. Archeologia szkła 7, 7-68.

Dekówna M. 1997. Prof. dr Zofia Kamieńska (4 V 1908 r. - 17 II 1996 r.). Archaeologia Historica Polona 6. Studia $z$ archeologii, historii i geografii historycznej, 275-285.

Dekówna M. 2005a. Czterdziestopięciolecie Polskiego Komitetu Narodowego Międzynarodowego Stowarzyszenia do Badań Historii Szkła. Archeologia Polski 50 (1-2), 221-226.

Dekówna M. 2005b. Rozwój metod badania znalezisk szkła w Polsce w latach 1930-2000. Acta Universitatis Nicolai Copernici. Archeologia 29. Archeologia szkła 9, 3-40.

Dekówna M. 2008. Prof. dr hab. Witold Hensel - badacz, organizator, dydaktyk. Zarys działalności. Archeologia Polski 53 (1), 55-62. 
Dekówna M. [2010] 2015. The glass from Cösitz (Zörbig), Sachsen-Anhalt, and the origins of non-alkaline leadsilica glass from European finds. The state of research in outline. Archaeologia Polona 48, 260-287.

Dekówna M. 2016. Prof. dr inż. Włodzimierz Świetlik (18.10.1922 - 27.07.2016). Archeologia Polski 61, 368-370.

Dekówna M., Dymaczewska U. 2015. Fragment naczynia szklanego z napisem, znaleziony w Odercy (Bułgaria). Archeologia Polski 59, 231-269.

Dekówna M., Purowski T. 2012. Znaleziska związane ze szklarstwem oraz okazy z kwarcu ze stanowiska Janów Pomorski 1. (W:) M. Bogucki, B. Jurkiewicz (red.), Janów Pomorski, stan. 1. Wyniki ratowniczych badań archeologicznych w latach 2007-2008, 1:3. Analizy. Elbląg, 65-260.

Dekówna M., Purowski T. 2016. Paciorki szklane. (W:) A. Buko (red.), Bodzia. Elitarny cmentarz z poczatków państwa polskiego. Warszawa, 153-205 + Katalog paciorków szklanych z Bodzi, stan. 2, na płycie CD.

Dekówna M., Szymański A. 1971. Badanie technik produkcji wczesnośredniowiecznych paciorków szklanych metodami petrograficznymi. Slavia Antiqua 18, 283-309.

966-1966. 1000 lat... 1966. 966-1966. 1000 lat polskiego szkła. Szkło i Ceramika 9, 225-284.

Kamieńska Z. 1966. Współpraca międzynarodowa w zakresie badań nad historią szklarstwa. Kwartalnik Historii Kultury Materialnej 14 (4), 727-730.

Karwowski M. 1997. Keltische Glasfunde im polnischen Gebiet, Przeglad Archeologiczny 45, 33-71.

Karwowski M. 2004. Latènezeitlicher Glasringschmuck aus Ostösterreich. Wien.

Karwowski M. 2012. Die Glastechnik und ihre Entwicklung in der Latène-Kultur - fremder Einfluss oder eigene Kreativität? (W:) Technologieentwicklung und -transfer in der Hallstatt- und Latènezeit. Beiträgezur Ur- und Frühgeschichte Mitteleuropas 65. Langenweissbach, 243-252.

Kiersnowski R. 2000. Wspominając Aleksandra Gieysztora: w „Millenium”. Przeglad Historyczny 91 (1), 61-67.

Kokora K. 2016. Paciorek ze szkła ołowiowo-krzemowego znaleziony w Wolinie. Archeologia Polski 61, 171190.

Kucharczyk R. 2011. Glass. (W:) S.E. Sidebotham, I. Zych (red.) Berenike 2008-2009. Report on the excavations at Berenike, including a survey in the Eastern Desert. Warszawa, 83-111.

Kunicki-Goldfinger J.J., Freestone I.C., Gilderdale-Scott H., Ayers T., McDonald I. 2014. Problematyka badań witraży średniowiecznych. Archeologia Polski 59, 47-78.

Labuda G. 1987. Witold Hensel. Szkic do portretu. (W:) G. Labuda, S. Tabaczyński (red.), Studia nad etnogeneza Stowian i kulturq Europy wczesnośredniowiecznej 1. Wrocław-Warszawa-Kraków-Gdańsk-Łódź, 5-9.

Le verre... 1963. Le verre en Pologne. Bulletin des J ournées I nternationales du Verre 2, 13-94.

Olczak J. 1959. Millenium - także szklarstwa polskiego. Szkło i Ceramika 10 (4), 95-98.

Olczak J. (J.O.) 1960. Powstanie Polskiego Komitetu Narodowego w ramach, „Journées Internationales du Verre’. Z otchłani wieków 26 (4), 359-360.

Olczak J. 1964. Stan badań nad szklarstwem wczesnośredniowiecznej Słowiańszczyzny. Slavia Antiqua 11, 301-349.

Olczak J. 1968. Wytwórczość szklarska na terenie Polski we wczesnym średniowieczu. Studium archeologiczno-technologiczne Wrocław-Warszawa-Kraków.

Olczak J. 1984. Archeologia w badaniach nad średniowiecznym i nowożytnym hutnictwem szkła w Polsce. Acta Universitatis Nicolai Copernici. Archeologia 10, 51-64.

Olczak J. 1987a. Główne kierunki badań historii szkła w Polsce. Acta Universitatis Nicolai Copernici. Archeologia 12. Archeologia szkła 2, 11-24.

Olczak J. 1987b. Wytwórczość szklarska we wczesnym średniowieczu. (W:) Z. Kamieńska (red.), Polskie szkło do połowy XIX wieku. Wrocław-Warszawa-Kraków-Gdańsk-Łódź, 27-40.

Olczak J. 1991. Wprowadzenie do problematyki dziejów szkła w Polsce. Acta Universitatis Nicolai Copernici. Archeologia 18. Archeologia szkła 4, 9-16.

Olczak J. 1992. Posiedzenie Polskiego Komitetu Narodowego l'Association Internationale pour l'Histoire du Verre poświęcone omówieniu kierunków badań prowadzonych przez polskich archeologów i historyków szkła. Acta Universitatis Nicolai Copernici. Archeologia 20. Archeologia architektury 2, 121-126.

Olczak J. 1998. Produkcja szkła $w$ rzymskim $i$ wczesnobizantyjskim Novae. Toruń.

Pankiewicz A., Siemianowska S., Sadowski K. 2017. Wczesnośredniowieczna biżuteria szklana z głównych ośrodków grodowych Śląska (Wrocław, Opole, Niemcza). In pago Silensi. Wrocławskie Studia Wczesnośredniowieczne 3. Wrocław.

Polskie szkło... 1974. Polskie szkło do połowy 19 wieku. Z. Kamieńska (red.). Wrocław-Warszawa-KrakówGdańsk. 
Polskie szkło... 1987. Polskie szkło do połowy XIX wieku. Z. Kamieńska (red.). Wrocław-Warszawa-KrakówGdańsk-Łódź.

Principes... 2002. Principes de description des verres anciens depuis les temps les plus reculés jusqu'au $X I I I^{\mathrm{e}}$ siècle de n.è ( $D$ 'après l'analyse du matériel archéologique du Centre, de l'Est et du Sud-Est de l'Europe et de la Transcaucasie). M. Dekówna, J. Olczak (red.). Warszawa-Toruń.

Purowski T. 2007. Przedmioty szklane odkryte na grodzie ludności kultury łużyckiej w Wicinie, stan. 1. Archeologia Środkowego Nadodrza 5, 75-172.

Purowski T. 2012. Wyroby szklane w kulturze tużyckiej w międzyrzeczu Noteci i środkowej Odry. Studium archeologiczno-technologiczne. Warszawa.

Purowski T., Dzierżanowski P., Bulska E., Wagner B., Nowak A. 2012. A study of glass beads from the Hallstatt C-D from southwestern Poland: Implications for glass technology and provenance. Archaeometry 54 (1), 144-166.

Purowski T., Kępa L., Wagner B. 2016. Glass on the Amber Road: the chemical composition of glass beads from the Bronze Age in Poland. Archaeological and Anthropological Sciences. https://link.springer.com/ article/10.1007/s12520-016-0443-8.

Purowski T., Wagner B. 2015. Badania składu chemicznego szkieł odkrytych na osadzie kultury lateńskiej w Podłężu koło Krakowa. Przegląd Archeologiczny 63, 125-146.

Siemianowska S. 2015. Analiza zabytków szklanych i szkliwionych z badań przy ul. św. Idziego na Ostrowie Tumskim we Wrocławiu. (W:) A. Limisiewicz, A. Pankiewicz (red.), Kształtowanie się grodu na wrocławskim Ostrowie Tumskim. Badania przy ul. św. Idziego. In pago Silensi. Wrocławskie Studia Wczesnośredniowieczne 1. Wrocław, 261-284.

Stawiarska T. 1984. Szkła z okresu wpływów rzymskich z północnej Polski. Studium technologiczne. Bibliotheca Antiqua 19, Wrocław-Warszawa-KrakówGdańsk-Łódź.

Stawiarska T. 1987a. Alkaline and calcium-magnesium raw materials used for melt of the ancient glass (me- thods of comparison). Archaeologia Polona 25/26, 209-224.

Stawiarska T. 1987b. Metody porównań składów chemicznych szkieł zabytkowych ze szczególnym uwzględnieniem okresu wpływów rzymskich. Acta Universitatis Nicolai Copernici. Archeologia 12. Archeologia szkta 2, 35-49.

Stawiarska T. 2014. Roman and early byzantine glass from Romania and northern Bulgaria. Archaeological and technological study. Bibliotheca Antiqua 24, Warszawa.

Stolpiak B. 1988. Szkło w kulturze społeczeństw przeworskich Kujaw - aspekt technologiczny. (W:) A. CoftaBroniewska (red.), Kontakty pradziejowych społeczeństw Kujaw z innymi ludami Europy. Inowrocław, 229-265.

Stolpiak B. 1989. Z metodologicznych problemów klasyfikacji wytworów szklanych. Acta Universitatis Nicolai Copernici. Archeologia 14. Archeologia szkła 3, 3-11.

Szczapowa J.L. 1973. Zasady interpretacji analiz składu szkła zabytkowego. Archeologia Polski 18 (1), 15-72.

Ŝapova Û.L. 1983. Očerki istorii drevnego steklodeliâ (po materialam doliny Nila, Bližnego Vostoka i Evropy). Moskva.

Ščapova J.L. 1975. Le verre byzantin du Ve-XII ${ }^{\mathrm{e}}$ siècles. (W:) V. Cubrilović (red.), Srednjovekovno staklo na Balkanu (V-XV vek). Zbornik radova sa međunarodnog savetovanja održanog od 22. do 24. aprila 1974. u Beogradu. Beograd, 33-48.

Tabaczyńska E. 1977. L’officina vetraria. (W:) L. Leciejewicz, E. Tabaczyńska, S. Tabaczyński, Torcello, scavi 1961-1962. Monografie dell'Istituto Nazionale d'Archeologia e Storia dell'Arte III. Roma, 89-153.

Wajda S. 2014. Wyroby szklane. (W:) H. Karwowska (red.), Średniowieczne cmentarzysko w Czarnej Wielkiej, stan. 1, woj. podlaskie (badania 1951-1978) 2. Białystok, 57-103.

Żuchowska M. 2016. Importowane naczynia szklane w Chinach w I tysiącleciu n.e. Archeologia Polski 61, 77-112. 


\section{STUDIES ON THE ORIGINS OF GLASSMAKING AND GLASSWARE IN POLAND: AN OUTLINE OF PROBLEMS AND RESEARCH METHODS}

\section{SUMMARY}

The discovery of relics initially interpreted as a glasswork from the $11^{\text {th }}$ century that occurred in Kruszwica in 1953 (Fig. 1; Cofta 1954, 224, 225; 1955) was followed by increased interest in glassware found during excavations in Poland. Even though later performed chemical and petrographic analyses of raw material as well as the analysis of the furnace construction and hearths revealed that this structure cannot be associated with glassmaking (Biezborodow, Olczak 1964), studies on this type of production became more popular. In the history of research on historical glass a few periods can be distinguished.

The first period that finished around the first half of the 1950s was characterised by brief and mostly restricted to the appearance descriptions of the glass artefacts. Usually, no attention was paid to the technological features. This period is not included in the paper. In accordance with the conference's subject, the state of sources and research in the following years were, due to limits, very briefly discussed.

Studies on glass-related finds were conducted in Poland on two levels: 1 . by institutions related to contemporary glass industry, 2 . by archaeologists and historians in cooperation with chemists, physicians and technologists.

\section{From 1950s until the end of the 1960 s. The millennial studies. $G$ athering sources. Development of organisational structures. First publications}

The increased number of glass-related finds (Wolin, Opole, Wrocław and, apart from the mentioned discovery from 1953, also later finds from Kruszwica) as well as first evidence of glass production in the area of Poland can be regarded a result of excavations of the main early Piast centres that were done as part of preparations for the celebration of The $1000^{\text {th }}$ Anniversary of the Polish State. Interested in the possible existence of local glass production in Poland were mostly institutions associated with glass industry. In the late 1950s Glass Section of the Association of Engineers and Technicians of Chemical Industry applied to Prof. Stanisław Lorentz, the director of the Head Office of Museums and Heritage Protection at the Ministry of Culture and Arts, for including the research on the origins of glassmaking in Poland in the millennial studies. As a result of this programme, a special edition of the journal Szkło i Ceramika (Fig. 2: 1; 966-1966. 1000 lat... 1966) was published in cooperation with archaeologists and his- torians. Also, an academic session was organised in Krosno in 1966.

The other research trend was represented by a team consisting of archaeologists, art historians, chemists and technologists from the Polish National Committee of "Journées Internationales du Verre" (Association Internationale pour l'Histoire du Verre since 1967) who worked under the supervision of Prof. Dr. Zofia Kamieńska, the Vice-President of the Committee. During that time first study summaries (Fig. 2: 2,3; Le verre... 1963; Polskie szkło... 1974; 1987) as well as the first monograph on early medieval glassmaking in Poland (Olczak 1968) were published in Belgium and Poland. There was a lot of international discussion on methods of analysing historical glass and also contacts between Polish and foreign scholars who specialised in the history of glass were developed (Figs. 3-6).

\section{From the 1970 s to the turn of the 21st century. Post-millennial studies. Theoretical basics and research methods. Significant increase in the number of publications}

The most characteristic feature of this period is the process of establishing research methods: analysis of chemical composition of glass (see: Dekówna 1980, 7; $2005 \mathrm{~b}, 15$ ), processing the results of chemical analysis (table 1; Szczapowa 1973; 1975; 1983; Dekówna 1975; 1990; Stawiarska 1984) and their interpretation (Fig. 7; Stolpiak 1989; Dekówna 1980, 22-38; 1988), studies on glass production techniques (Dekówna, Szymański 1971), rules of describing glass objects of various categories (Fig. 8; Principes... 2002).

All these initiatives, based on the constantly increasing number of sources, contributed to the emergence of new scientific discipline - the history of glass. They also allowed for a reinterpretation of the records. For example, a thesis was advanced that in the Early Middle Ages mainly workshops processing cullet and semi-finished glass functioned in Poland. Only in the area of the left-bank settlement in Wrocław glassworks that produced glass from raw material existed (Dekówna 1974; 1980, 239 nn.; 1988).

The number of various publications on glass finds not only from Poland, but also from other countries where Polish scientist were invited for research (see an overview of the works: Dekówna 2005b) distinctly grew in the discussed period. Comprehensive works on prehistoric glass 
(e.g. Karwowski 1997; Purowski 2007), somehow neglected in the previous periods, were released.

\section{The early 21st century. Situation at the time of the second millennial $\left(1050^{\text {th }}\right)$ anniversary. New young researchers. Stabilization of methodology}

Polish National Committee of the Association Internationale pour l'Histoire du Verre still functions. Presently, it is affiliated at the Institute of Archaeology and Ethnology of the Polish Academy of Science in Warsaw.

Deep interest in the history of glass can be noticed among young archaeologists. Wrocław is an outstanding centre in this respect, as international conferences are regularly organised there, and the researchers reanalyse glass- related finds from the most important strongholds of the region (including Wrocław, Opole, Niemcza), basing their studies on comprehensive physical and chemical analyses (Siemianowska 2015; Pankiewicz et al. 2017). Research on prehistoric glass is developing and new methods used by scholars from the Western Europe are introduced (Purowski et al. 2012; Purowski et al. 2016; Karwowski 2012; Purowski, Wagner 2015). Nevertheless, participation of Polish scholars in international congresses and other academic meetings is becoming constantly rarer, which is worrying. Among the released publications there are also studies of Polish scientists on glass discovered outside Poland (Dekówna [2010] 2015; Dekówna, Dymaczewska 2015; Karwowski 2004; Kucharczyk 2011; Kunicki-Goldfinger et al. 2014; Stawiarska 2014; Żuchowska 2016).

\section{Adres Autorki:}

Prof. dr hab. Maria Dekówna

Instytut Archeologii i Etnologii PAN

Al. Solidarności 105

00-140 Warszawa

e-mail: archeologia.polski@wp.pl 